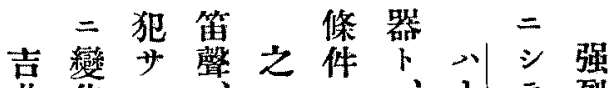

并花几等

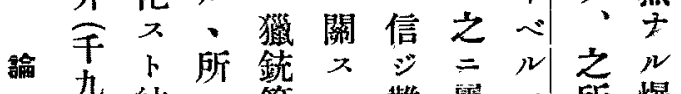

說克結筑等等籍第第

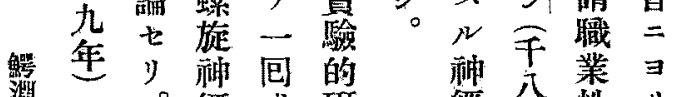

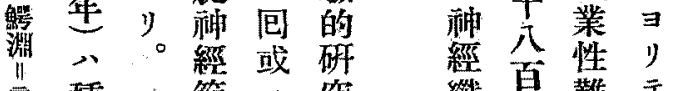

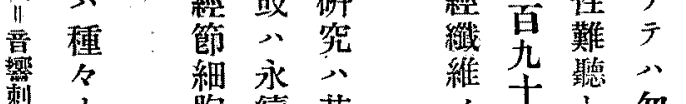

赛赛 研緹

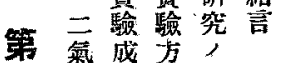

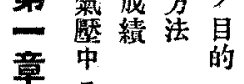

$\overrightarrow{\vec{\theta}}$

鹤占

梀川

戟

胞續甚萎年点圽

緒

二

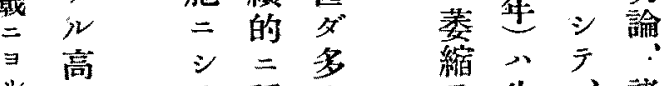

德 离我種多、生、諸

器, ‘證前䠦種

障音之十皖明倳狀,

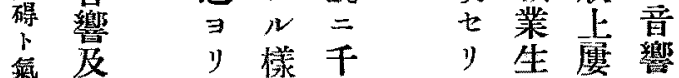

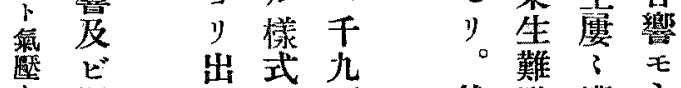

害 謇

神草然聽遭永

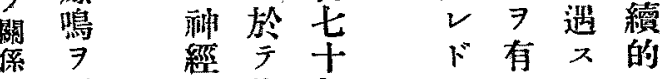

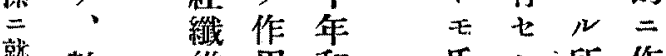

唯數維角和氐为所作

向次七过, 者; 用

叉 $゙$ シ 父所, モ

八犯 メ砲見聽，止

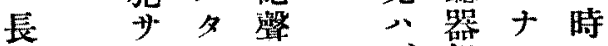

時 ᄂ,

旦終年孚之織。聽

猽来, 動 老的气

二 器研物人研障

作官究實性究碍

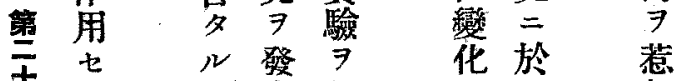

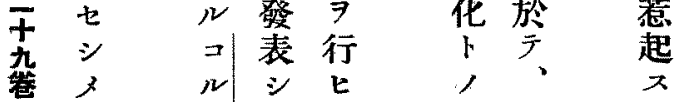

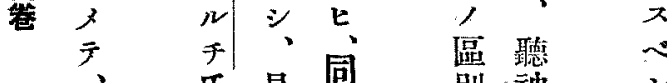

吾氏 㗊是等繁称

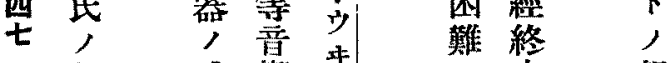

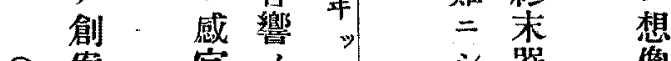

第案宾,

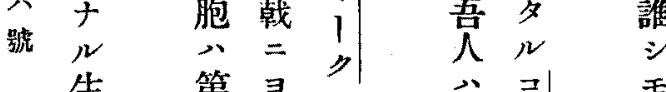

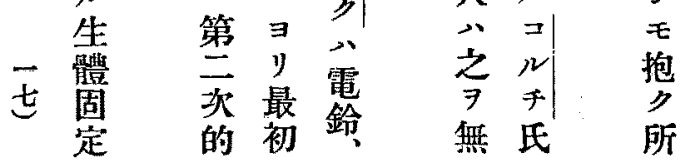

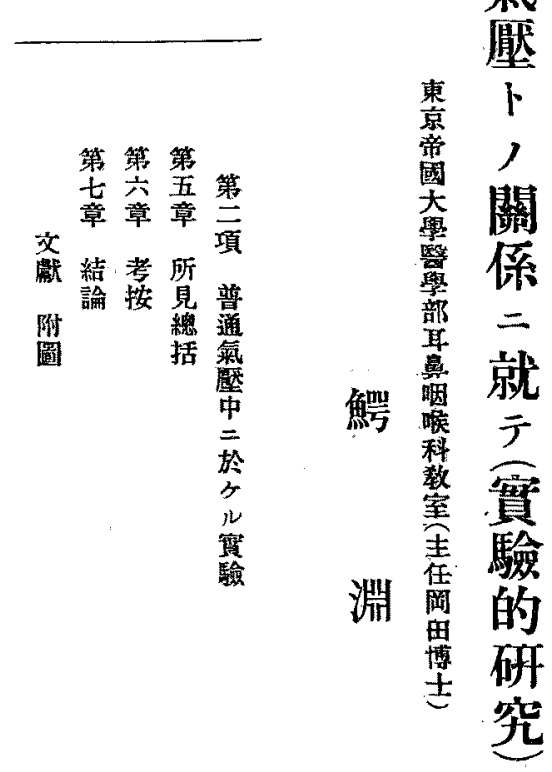

源 
再

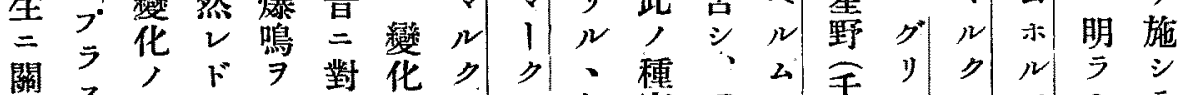

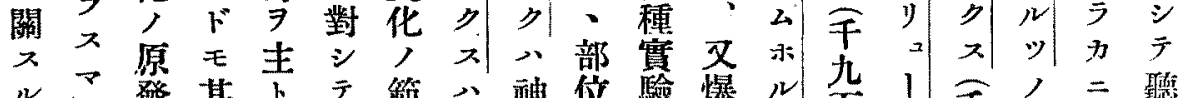
論球部, 其卜

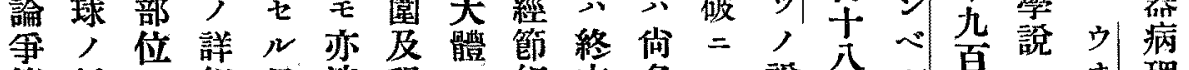

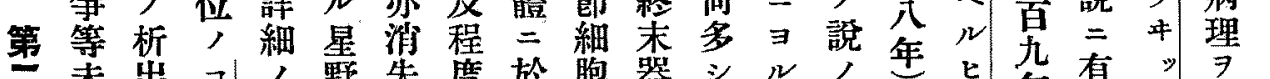
三未出コ, 野失度於胞器

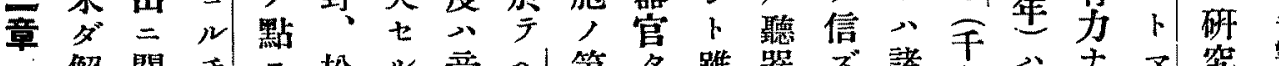
解 關 テ三松

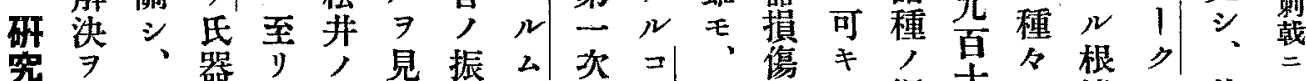

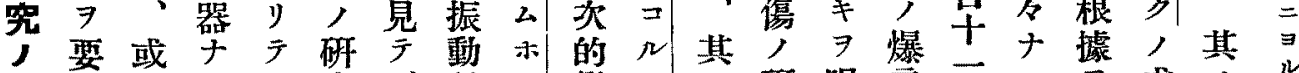

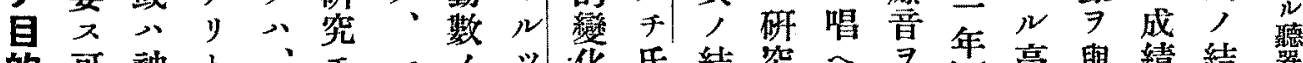

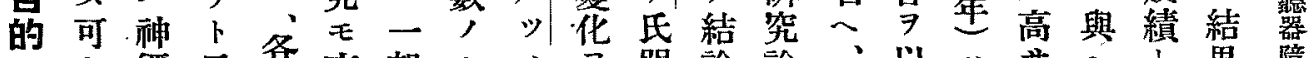

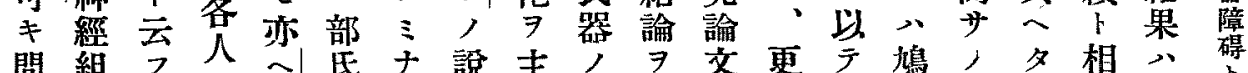
問組 フ

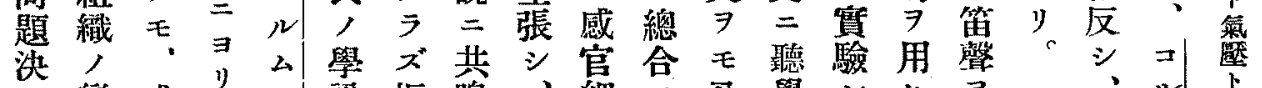

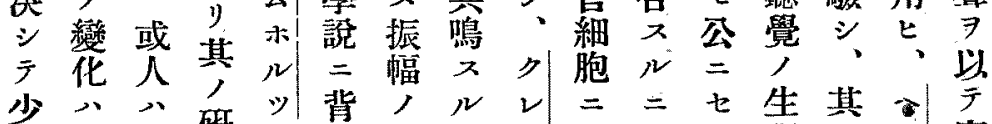
シ退其研, 究背大

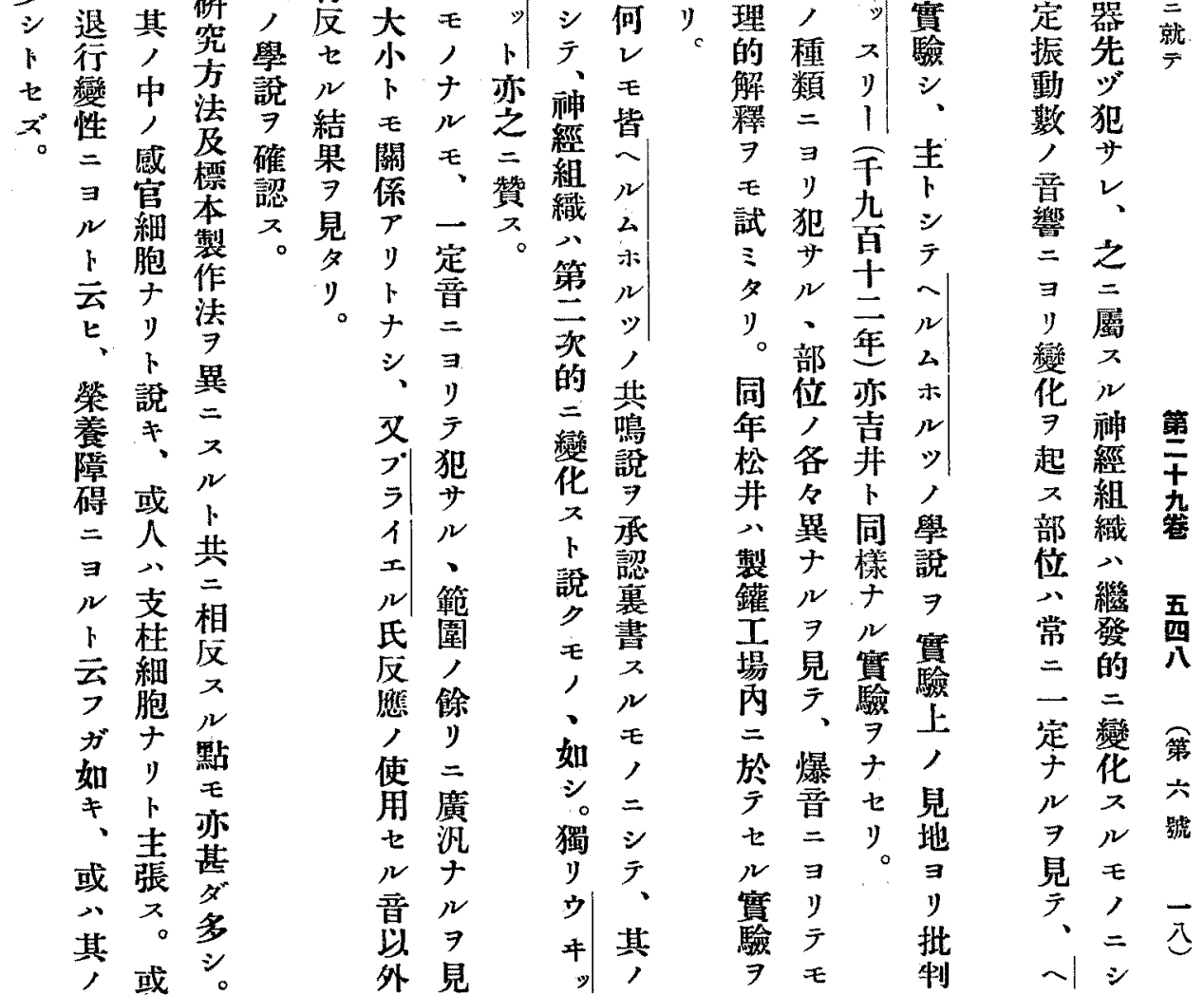






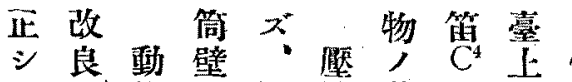

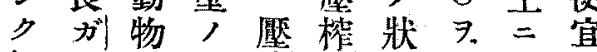

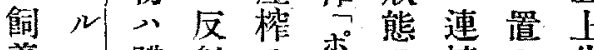

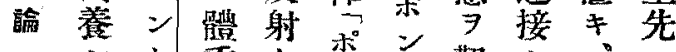

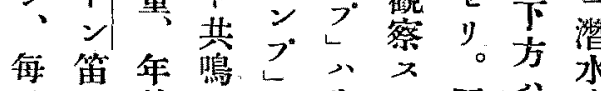

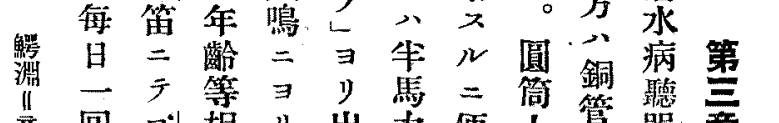

回 ブ相り出力便上管器

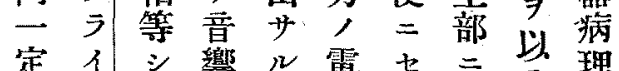

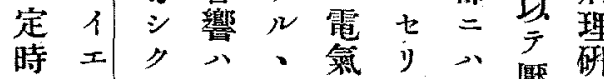

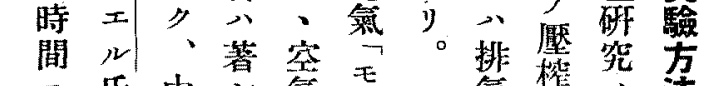

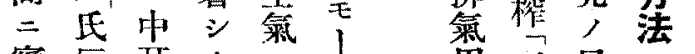

䁈更多年书目

驗礁健增狀少,

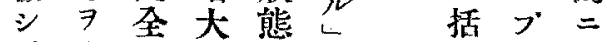

、检子

實 シ ル初從 $テ$ 連

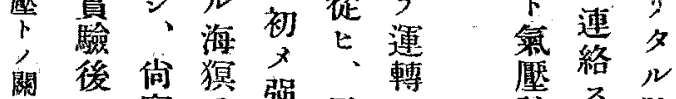

闗後䨘

就體噞使弱 7 年銅置

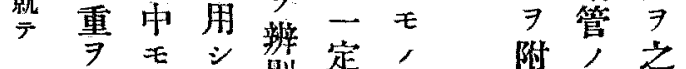

量膺、别足 = 入圓二

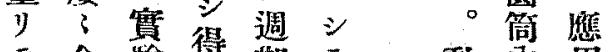

テ金驗得期

其屬

笑槊前暫

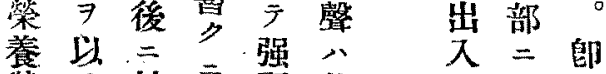

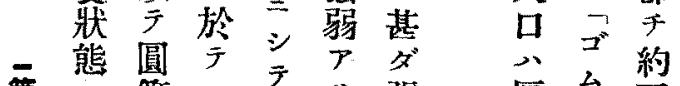

雷態简

干洼壁每不呩。烈管草

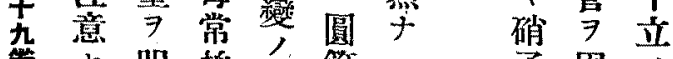

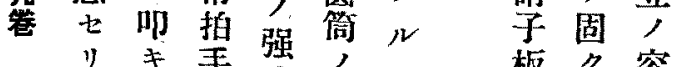

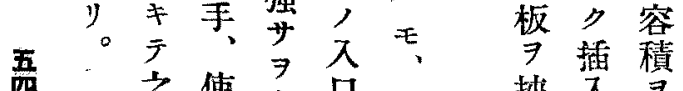

吾吾售有口常。摤入置

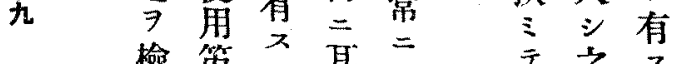

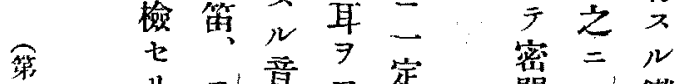

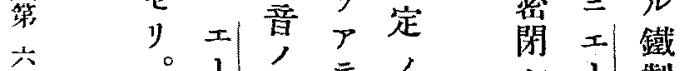

號動

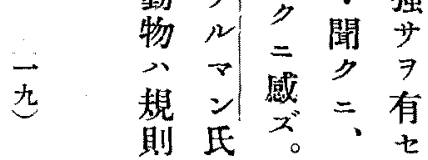

シ 1 製

デ 圆

實

驗 7 要

動 比

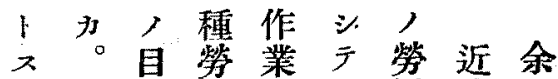

$N$ 又的働 二、働 時

二高心, 於氮者海本

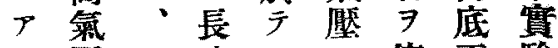

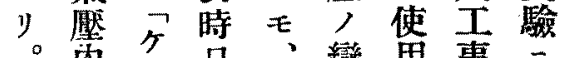

內! 日變角事

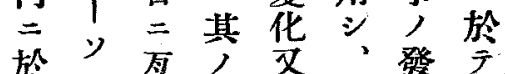

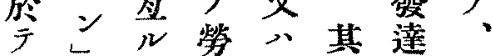

卑病時働高, 占

響, 八, 麾期共人

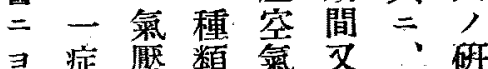

狀變二呼年年究

聽

器 $シ=y= \pm$ 㟫

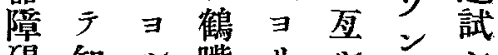

碍 知ル嘴りル上 シ

八

普レ種以ルアハ,

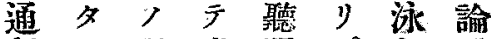

氣儿現岩器。氣爭

壓 聽象石障而鐘二

丙器 $卜 \quad \exists$ 碍 三 丙一

二障相碎 心テ三部

於碍俟》、是於，

ケ、于 等濳等尔解

$心$ 特 广相 水八決

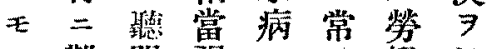

, 嚾 器强, 二働見

1 德 障烈一厴 $\Rightarrow$

如, 碍ナ般榨必

何或 $7 \mu$ 病空要

二物惹音埋戴下占

異 八起諳音

于是不, 共呼、星

$ル$ 等 $ル$ 刺 二吸大非

カ、音事韩臨ジナ、゙

主刺キ受上、㯌

卜韩 $\exists$ 周高道

$シ$ 二保ル知嶎工

原 シ モ, 㢳

其因難, 事下=

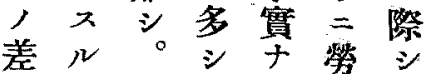

差的。广 学

翼モ郎而り。動 テ

$\exists=$ 余夏更數

知非, テ三モ百

ラザ 實 $コ$ 海, 數

ン驗, 底=繁 


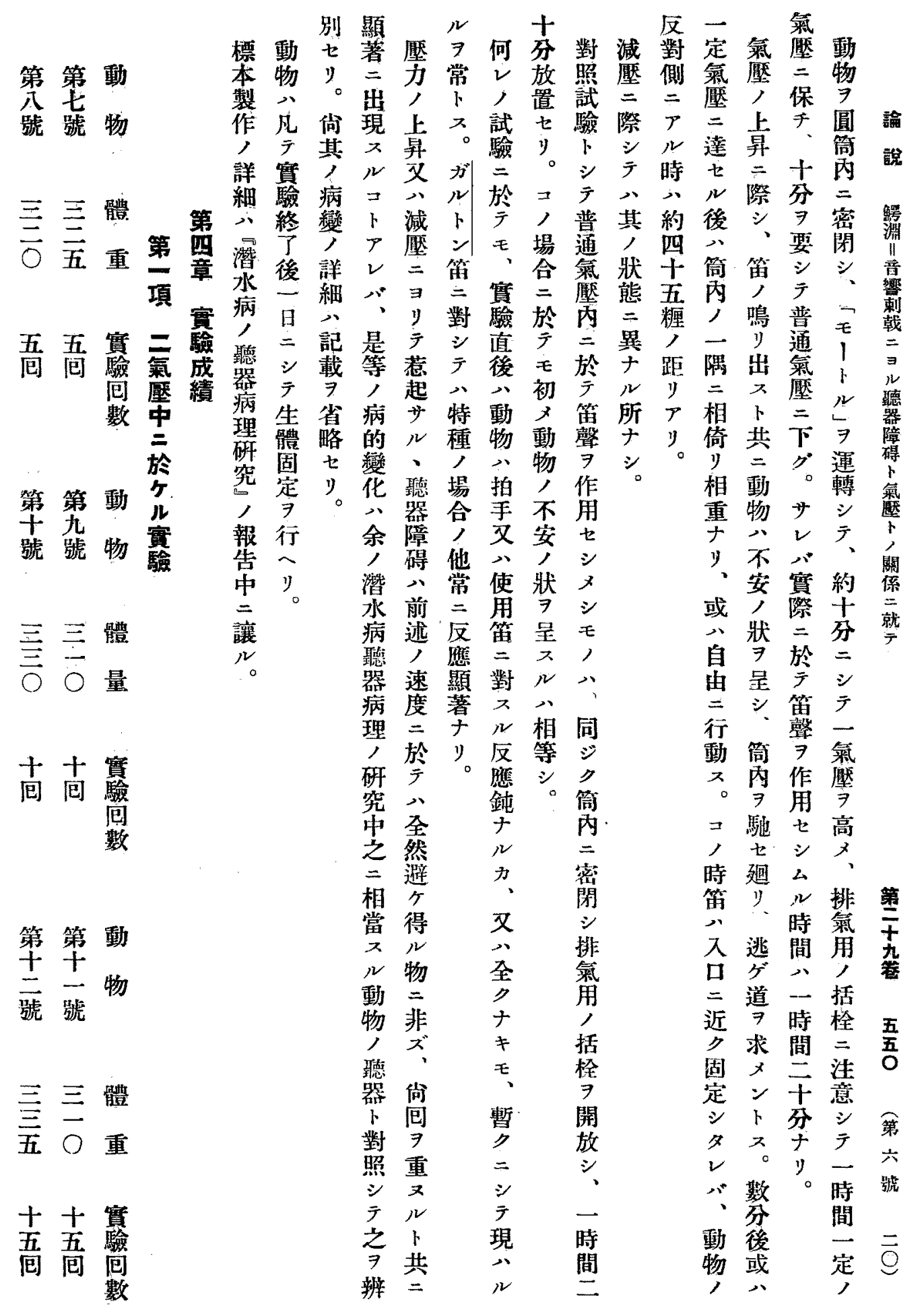




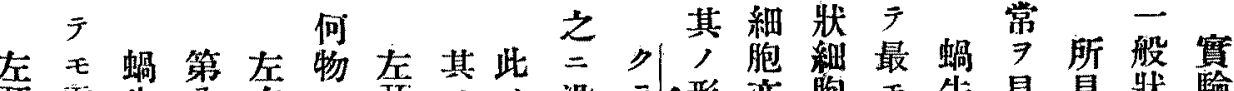

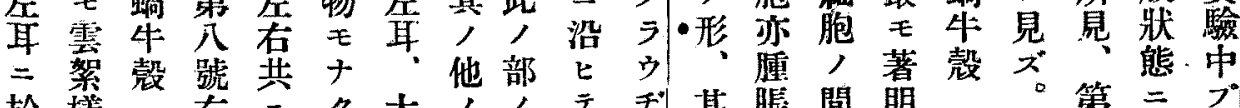

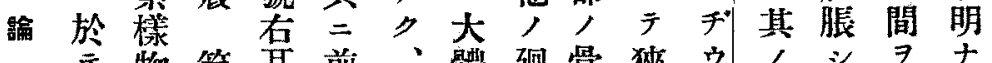

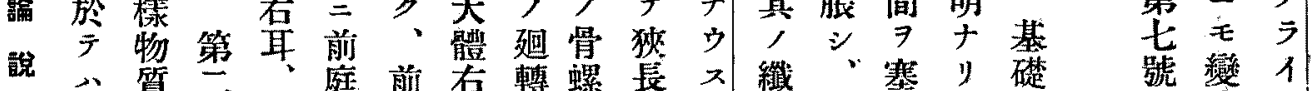

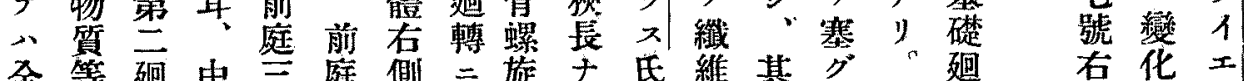

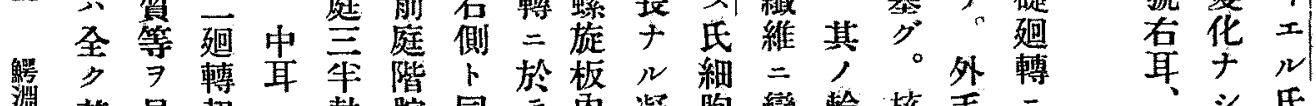

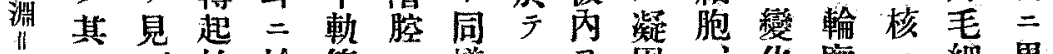

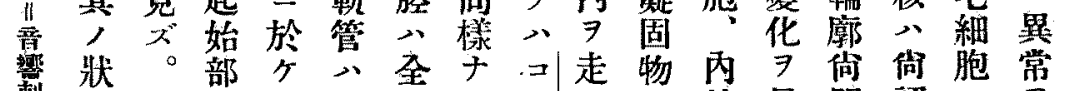
狀態 於變常清モ千神附螺 天゙白丈既見

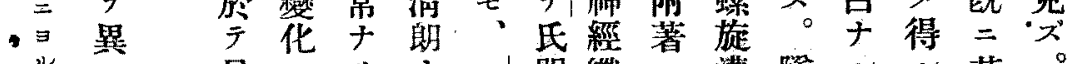

$$
\begin{aligned}
& \text {. } \\
& \text { 䮦 } \\
& \text { 窟 }
\end{aligned}
$$$$
=\quad \text { 自 }
$$

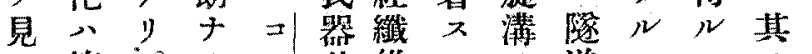$$
\text { 第 ○当。其維 }
$$

a)

F右

中 氏耳

耳 器 上

閵云称相

就

鼓㱠 モ

稍出

了第 血

弛 七稍

紱, 號了

渚舊

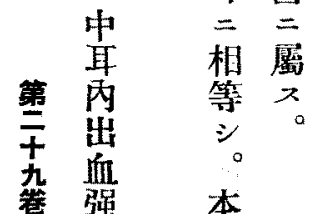

本

五小本

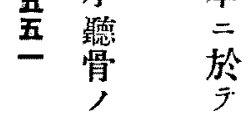

第周圄何

號

血廻

三垠轉

迴

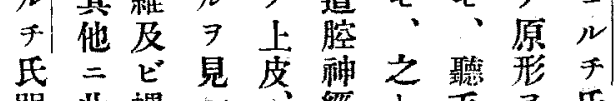

器此螺少經下毛

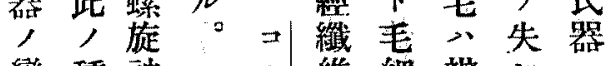

魂 種神

化, 經

稍 㮏就

囬

道

道㲾

胶

綡

經 等

纖

維椎

未

名是

问

變
华
呈
七
ズ。

ズ

里

膜

上

$\rightarrow$

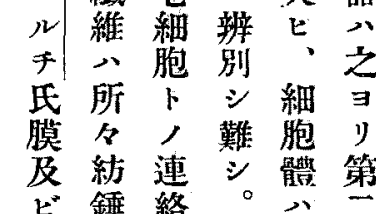

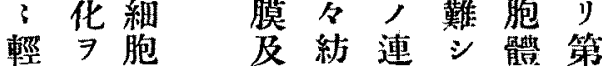

引) 猋 絡内腫 廹

氏 $=$ 認毛脤轉

名膜腫 細シ云

等 變 シ ク 八其行

化、、玷, 又

變 $\rightarrow$ 施核其境

化，見緩一; 界部

: $x^{2}$ 通形不分

唯り。常䯈㹈 $\exists$

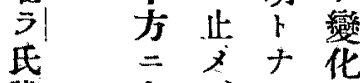

膜存、y、

上 上。聽 、來

八内丙监ン

時

二 桿 $x$ 二

霎牀。过迴

細ダ支䡜

胞 们起

二テ召始

$\therefore ル ト$ 部

末无外立於
米

中。反

耳 應

$=\quad=$

於編

于 化

鼓 來

膜。

周

緣卓

內 シ

面第

桘骨啹

把两

部苚

及 砧實

骨 霝

周 體

圍重

新 五

鮮瓭

減

出

血 第

見 八

皦

小 -

聽

關 7

節減 


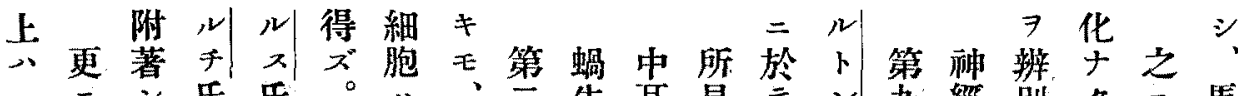

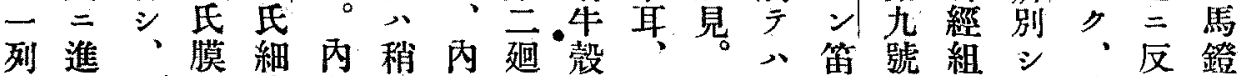

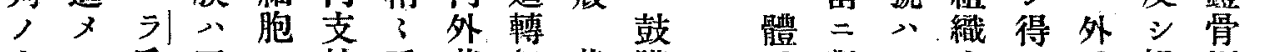
上 $心$ 氏正 $八$ 桂腫基起基膜重對一亦 皮了膜常其緗脤底始礎

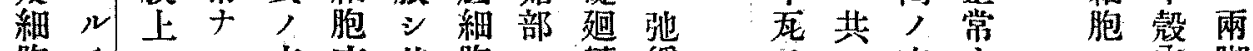
胞 $\forall=ル$ 支亦其胞二轉緩 $\quad \exists 三$ 㨁子, 丙脚

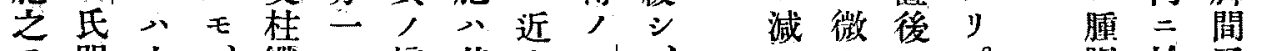

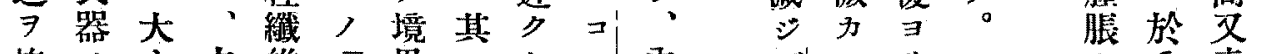

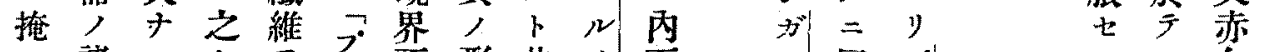
フ。諸

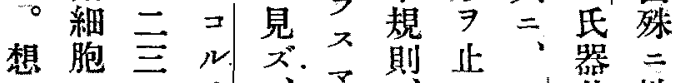

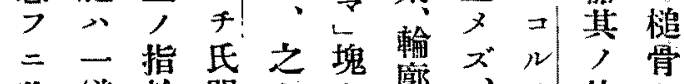

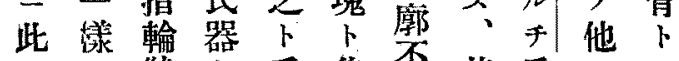

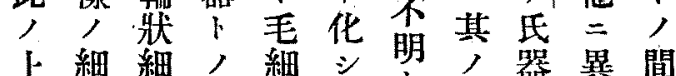

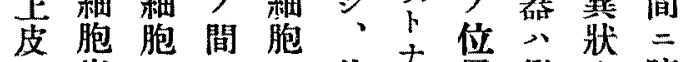

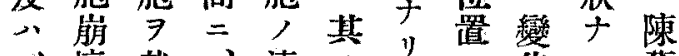

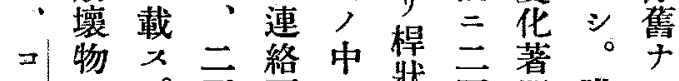

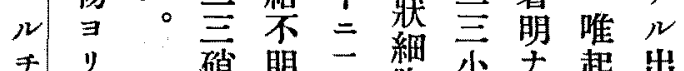

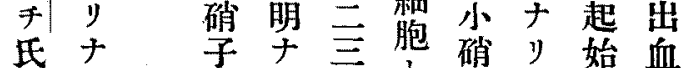
器 $⿻$ 秛り 破大球。核へ樣丽, ”。

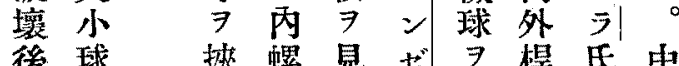
後球摤蝠見七゙灵柏氐中 內化。溝。民細上腔 外 三血, 外支, 胞二粘 螺、管細毛枉 ミ来零膜

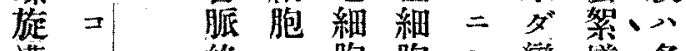

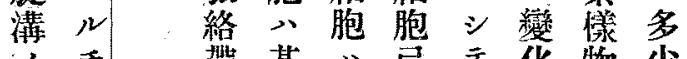

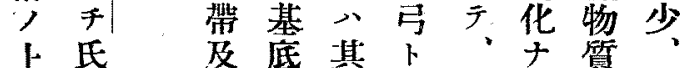

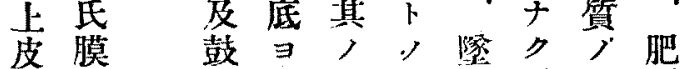

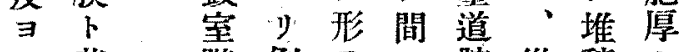
基階剥 $\Rightarrow=$ 腔從積 再礎腔離保霂神ッスル 生膜 七間外 $ル モ 。$ 織㯌 $ア$ 出

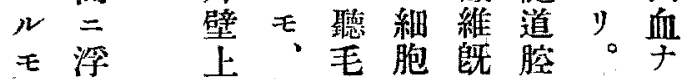

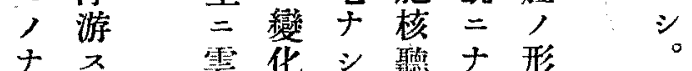

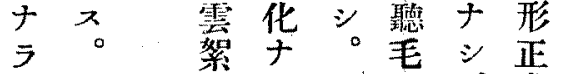

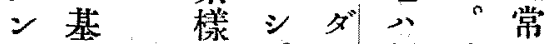
办礎:物信認外 中膜 一質 $=\mid$ テ メ毛近

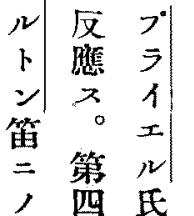
包原 反目應 應二陰 P $\rightarrow$ 性 り。體 ト 重ナ 珰第 娍宂 娍包胞氐

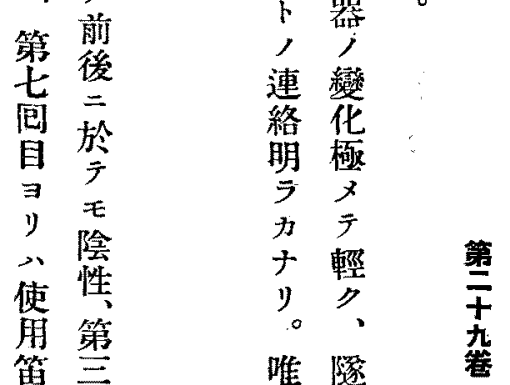
笛离 原,

應 前 せ 後 ズ

拍

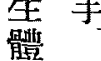

固 使 定 角 笛 值 前 $カ$
說

繯 晋 蟼 第球 輸三集 廓迴 積 明轉 $又$ 暸起 㜔 三始 テ 多於關 传節 關 考, 係 氏 細

聽 道

毛 腔

八 神

少經

存䌦

ス維 第

㜔京

モ

其走

$\frac{y}{z} \quad \equiv$

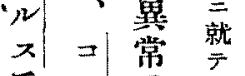




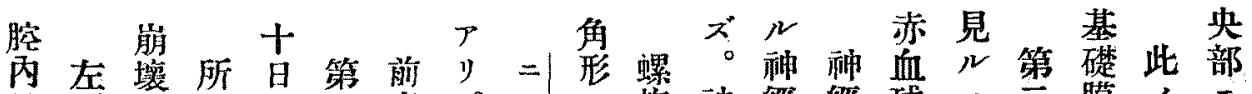

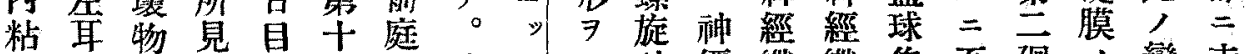

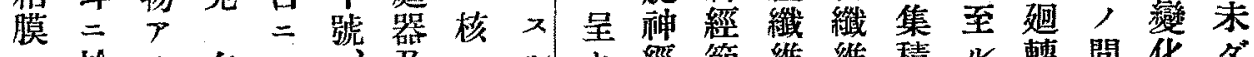

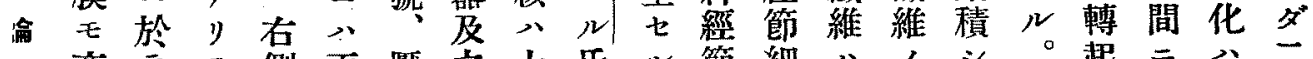

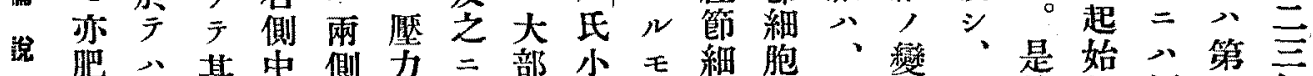

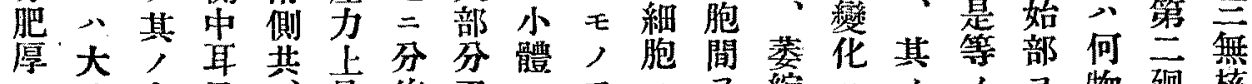

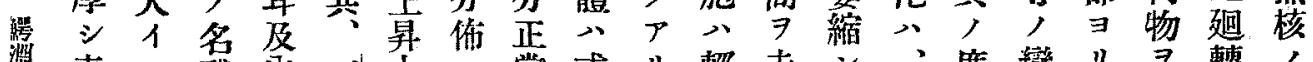

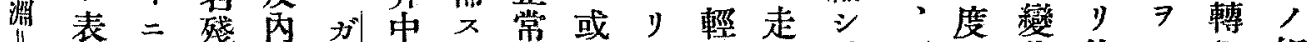
音面其 $尹$ 耳心定

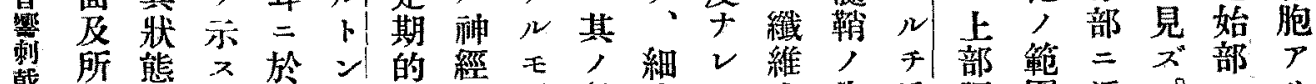

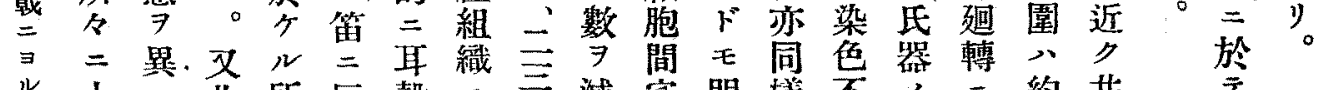

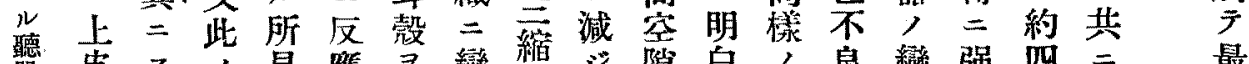
㽞皮

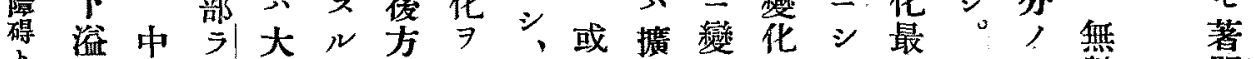
血耳觶, 二見濃一張化 $\exists$ F $モ$ 一 數明

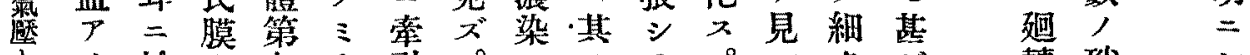

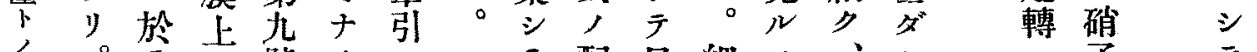

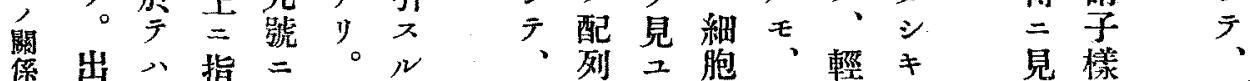

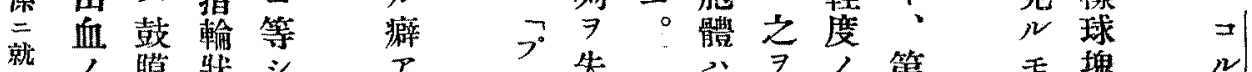

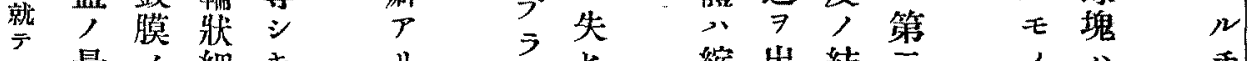

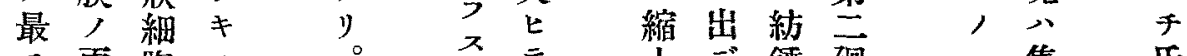

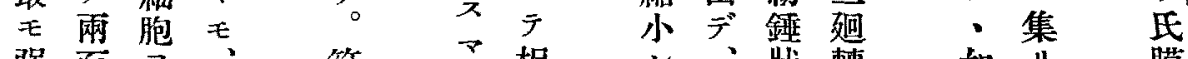
强面 $\ni 、$ 第、相 $、$ 牀轉如少膜

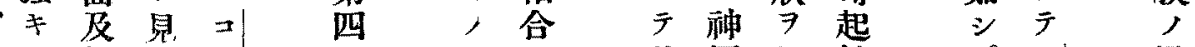

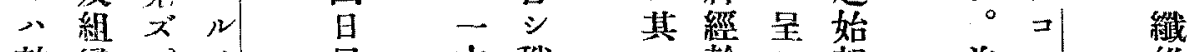

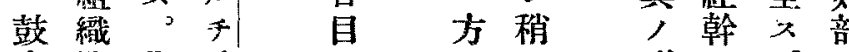

室間内氏 两 $=3$ 形 $=0$ 部出出器 至 偏大 尔合其於

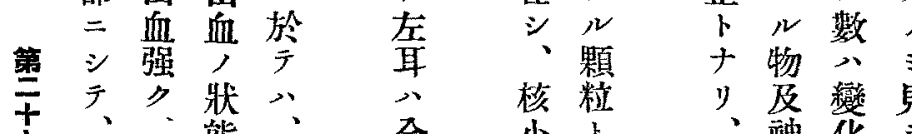

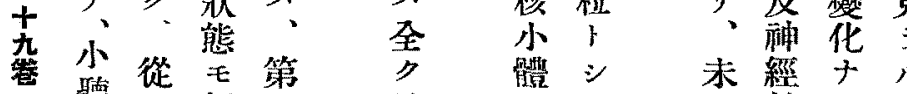

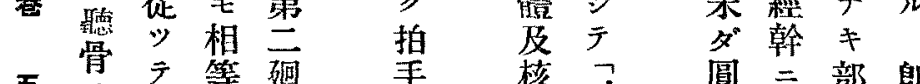

及索 $ラ$ 形於位

第殊 甚部

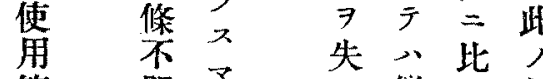

六䵭

笛明

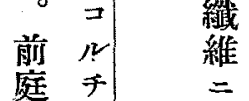

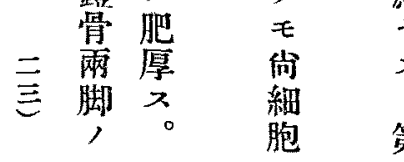

反

雖 見 孉 旋

七

第

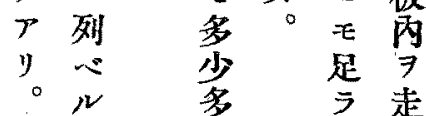

階

腟 器

,,+

外形平

壁 $尹$ モ

上 現

鼓シ 部

空、其

階遂,

膑 $=$ 基

外政底

壁, 》

$=\quad 2 \quad$ 㔀

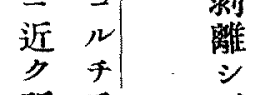

所氏

十 器
$=$ 马

之 


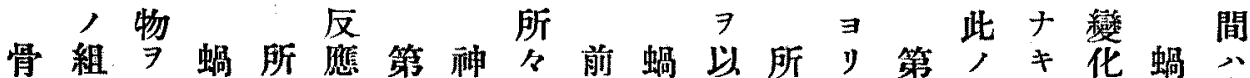

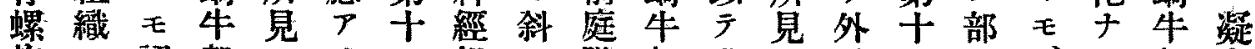

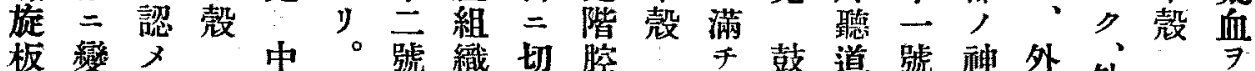

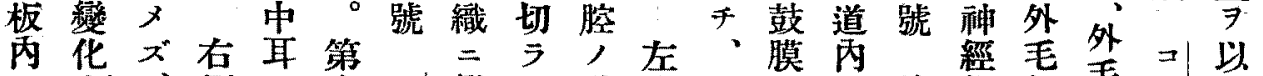

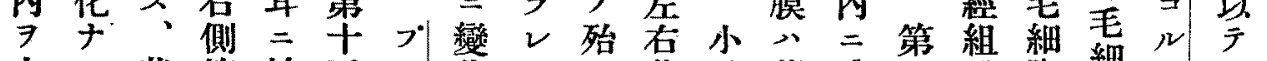

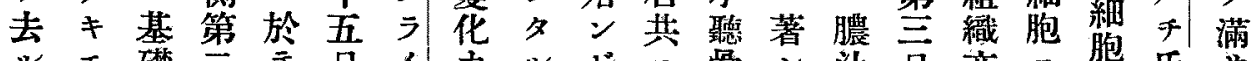

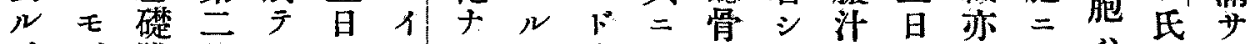

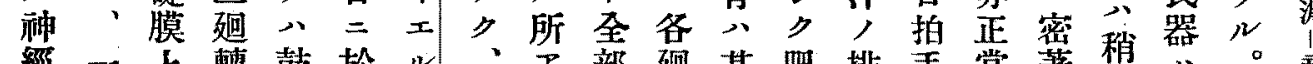

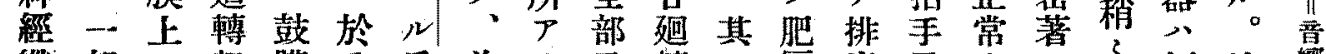

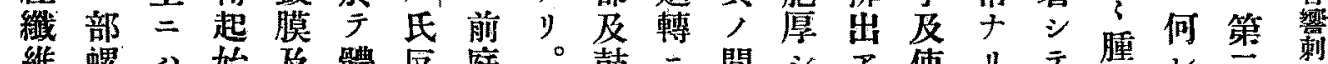

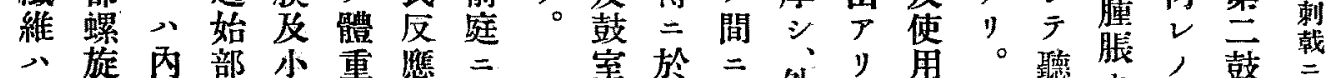

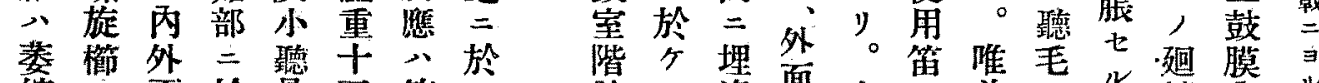
維当兩於骨五第 $三$ 膑

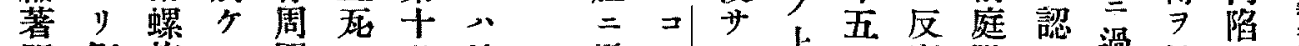

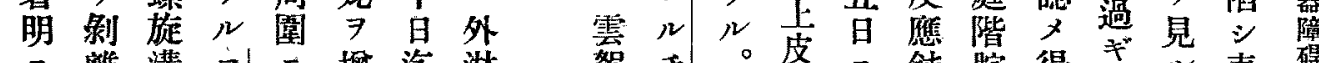

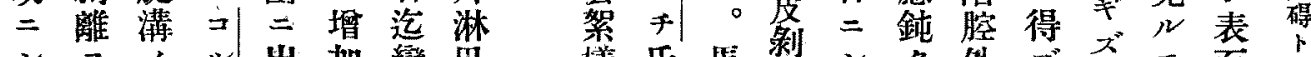
シス，

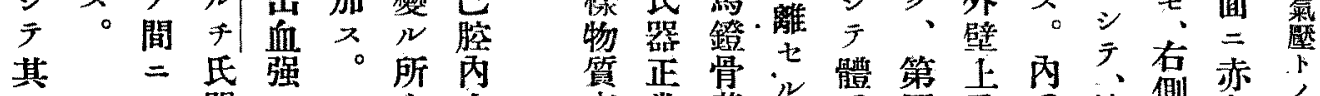
向器

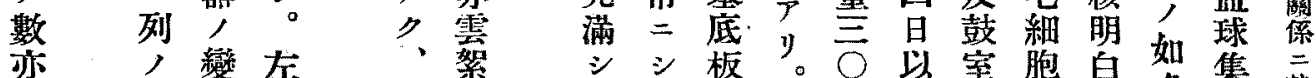

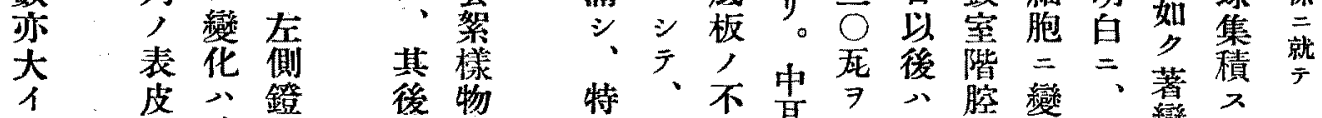

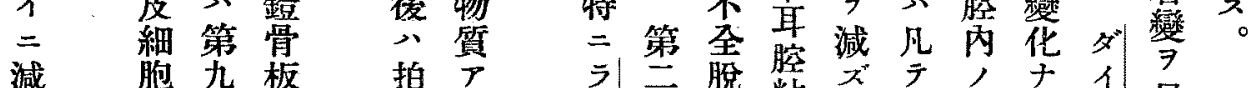

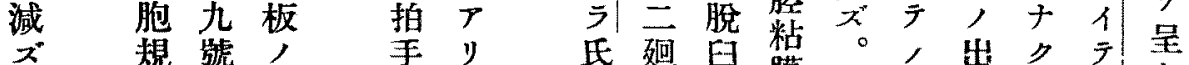

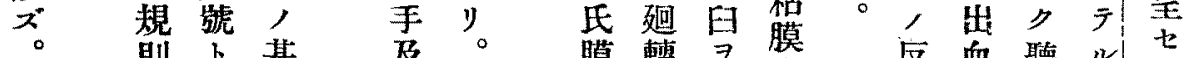

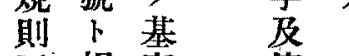
正相底 使 似板 用 ク 不笛

配 高 全 =

列度膜對 *十日 各。貝原

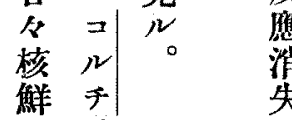

明 氏

于 膜

y.

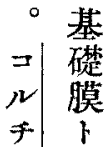

氏,

膜 間

其何

反

膜 䡜 $\exists$ 亦 上起見哥

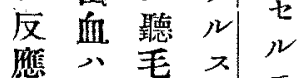

八部。厚

㷋 二

長於表

消稍明氏モ

失了三稩子

十西

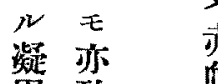

固㱠 血

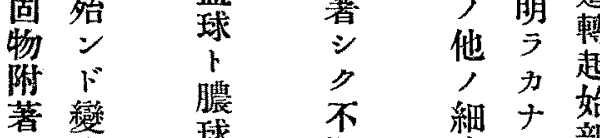

動度ナ、ト

物り。連 第

天华球活胞》、部

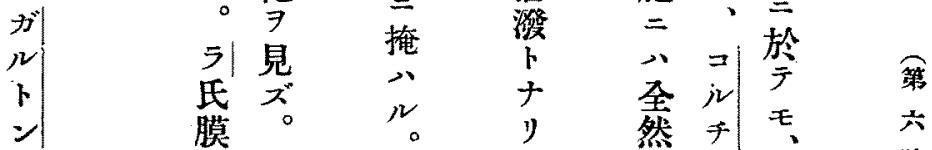

笛

膑

弛

微

肉

秋 氏 全

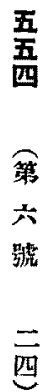

綗

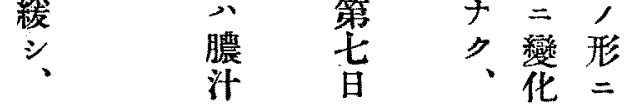

第华膜 體 


\begin{tabular}{|c|c|c|c|c|c|c|c|c|c|c|c|c|c|c|c|c|c|c|c|c|}
\hline & & & & & & & & & & & & $\begin{array}{l}T \\
z\end{array}$ & & & 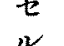 & & 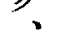 & 朵 & & \\
\hline & 第 & 䈨 & & & 糎 & t & 间 & 脤 & $\hat{\beta}$ & 1 & 螺 & & $\begin{array}{l}\text { 泳 } \\
\$\end{array}$ & 側 & $\Rightarrow$ & 䞤 & 核 & 2 & $=$ & \\
\hline & & - & 動 & & $\stackrel{1}{=}$ & シ & 實 & 㷠 & 認 & 壱 & 旋 & & , & $=$ & 見 & 轉 & 索 & 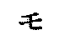 & 近 & 神 \\
\hline & 號 & 號 & 物 & & $\Sigma^{\prime}$ & $\not$ & 驗 & $=$ & $x$ & 頭 & 板 & & 原 & 於 & $N$ & $=$ & 條 & , & $\neq$ & \\
\hline & & & & & テ & テ & 中 & $\Rightarrow$ & ラ & J & , & & 形 & $\overline{7}$ & & 於 & 亦 & 多 & $E$ & \\
\hline & & & & & 反 & 發 & 槽 & ラ & $N$ & 珥㯖 & 触 & & 貿 & $\rightarrow$ & & $\overline{7}$ & 然 & シ & & \\
\hline & • & $\equiv$ & & & 慰 & x & 內 & ウ & 、 & 器 & 經 & & 塊 & 以 & & $\rightarrow$ & y & & 多 & 胙 \\
\hline & & 二 & 體 & & $\exists$ & $\mu$ & 動 & $F_{i j}$ & 著 & 所 & 纖 & & r & 上 & & $\overrightarrow{.}$ & 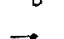 & 原 & 角 & 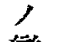 \\
\hline & 五 & 0 & 重 & 第 & 若 & 音 & 物 & ウ & 明 & 見 & 維 & & シ & 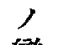 & & 般 & 又 & 形 & 形 & \\
\hline & & & & & 起 & 響 & ' & 지 & ナ & $=$ & 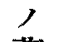 & & $\bar{T}$ & 嫩 & & $=$ & 核 & 質 & 7 & \\
\hline & & & & 项 & シ & $=$ & $7^{\circ}$ & 氏 & $N$ & 於 & 菱 & & 基 & 化 & & 雔 & ' & ， & 呈 & \\
\hline & & & & & 得 & $\exists$ & ラ| & 芴 & 䋈變 & $\bar{\jmath}$ & 紑不 & & 整 & z & & 化 & 消 & $\overrightarrow{a r u}$ & $x$ & \\
\hline & & 7 & 营 & xyt & $M$ & 4 & 1 & 月 & 化 & $z$ & 59 & & 搝 & $\exists$ & & T & 天 & 投 & 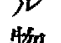 & \\
\hline & 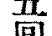 & 五 & 駕知 & 照 & 4 & 罚 & + & $=$ & 7 & 7 & 7 & & 上 & & & 3 & r & 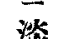 & 物 & \\
\hline & & & [C] & 㤎 & As & 2 & 氏 & W & 党: & 小 & & & 椟 & & & 唯 & 乇 & 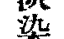 & J" & \\
\hline & & & & & $y$ & $=$ & 反 & 2 & x & 溜 & 神 & & 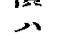 & 輕 & & 所 & , & シ & & \\
\hline & & & & & 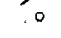 & 普 & 鹤 & 腫 & $v$ & 水 & 經 & & $N$ & 度 & & 8 & z & テ & & \\
\hline & 第 & 第 & & & 此 & 通 & $\exists$ & 脤 & $\therefore$ & 病 & 節 & & 0 & $\neq$ & & $=$ & ラ & $\because$ & $=1$ & \\
\hline & 四 & $\equiv$ & 動 & & $j$ & 氣 & 檢 & $F$ & ' & 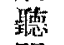 & 細 & & 倘 & ) & & 兹 & $\boldsymbol{T}$ & 其 & $\triangleq$ & \\
\hline & 號 & 號 & 物 & & 譪 & 壓 & x & 水 & 中 & 器 & 胞 & & $\Longrightarrow$ & en & & 係 & $y$ & 1 & $x$ & \\
\hline & & & & & 殮 & 内 & $N$ & 腫 & 耳 & 病 & ' & & $\therefore$ & E & & 樣 & & 境 & 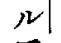 & \\
\hline & & - & & & $=$ & $=$ & $=$ & 㴍 & $=$ & 理 & 變 & & $\equiv$ & 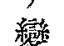 & & 物 & & 界 & 氏 & \\
\hline & 三 & 三 & & & M & 於 & 當 & 戀 & 於 & , & 化 & & 核 & 华 & & 質 & & 不 & 卜 & \\
\hline & & $\overrightarrow{\vec{n}}$ & 骨掌 & & 勇 & י י & 涌 & 性 & 7 & 研 & 筷 & & 自 & , & & 7 & & 明 & 慗 & \\
\hline & & & & & 等 & 巫 & 贫营 & $\exists$ & 諸 & $\begin{array}{l}\sharp \\
\exists\end{array}$ & 牙 & & 总 & 中 & & $\pi$ & & $v$ & & \\
\hline & & & & & 作 & 均 & 金 & $N$ & 變 & y & 號 & & $\mu$ & 岕 & & F & & $\mathcal{E}$ & 偝 & \\
\hline & & & & & 用 & 五 & 呞 & 內 & 化 & 得 & J & & $\mathcal{E}$ & 暗 & & & & , & & \\
\hline & & & 筫 & & セ & 糎 & 棒 & 容 & & צ & y & & , & & & 前 & & 多 & 量 & \\
\hline & $T$ & + & 驗 & & シ & ' & $\Rightarrow$ & , & 内 & $N$ & $v$ & & $\gamma$ & & & 庭 & & シ & & \\
\hline & 问 & 包 & 问 & & $\not$ & 高 & 以 & 析 & 耳 & 標 & r & & $y$ & f & & 階 & & 0 & 物 & נ \\
\hline & & & 數 & & $サ^{\prime \prime}$ & サ & $\bar{\zeta}$ & 出 & 外 & 本 & 相 & & & & & 腔 & & 細 & t & \\
\hline & & & & & N & 7 & 七 & & 淋 & $\mathrm{f}$ & (D) & & 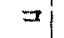 & $\Rightarrow$ & & 及 & & 胞 & & \\
\hline & & & & & 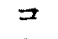 & 必 & 2 & 空 & 巴 & 比 & $\bar{J}$ & & $M$ & N & & 鼓 & & 核 & . & \\
\hline & 第 & 第 & & & $k$ & 要 & ガ & 洞 & 腟 & 䡚 & & & $F$ & $\neq$ & & 室 & & $\rightarrow$ & & \\
\hline & 兵 & 五 & 動 & & 勿 & r & & 形 & $=$ & シ & 右 & & 氏 & 氏 & & 階 & & 大 & 合 & \\
\hline & & 號 & 物 & & 論 & 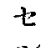 & $七$ & 成 & 於 & $\bar{y}$ & 側 & & 膜 & 器 & & 腔 & & 坐 & シ & \\
\hline & & & & & $\stackrel{t}{\prime}$ & 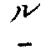 & 瓦 & 等 & ケ & 明 & $=$ & & $\vec{~}$ & 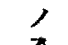 & & $=$ & & 繀 & テ & \\
\hline & $=$ & $=$ & & & 7 & & 全 & y & N & 7 & th & & 位 & 全 & & 於 & & 小 & 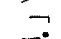 & \\
\hline & $=$ & 二 & 腈 & & & 一 & 震 & 5 & 虫 & $=$ & : & & 直 & 䉽 & & $\overline{7}$ & & 湆 & 7 & \\
\hline & 五 & 五 & 重 & & & 氣 & 塊 & z & 物 & 意 & $\gamma$ & & 常 & > & & $\pi$ & & 小 & ス & \\
\hline & & & & & & 廂 & 7 & & & 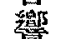 & 度 & & & 最 & & 球 & & 體 & 7 & \\
\hline & & & & & & $\exists$ & 槽 & & $=$ & 策 & 7 & & 畕 & 是 & & 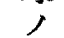 & & ass. & & \\
\hline & & & & & & 高 & 壁 & & $N$ & 战 & 異 & & 旋 & * & & 夕夕 & & 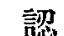 & , & \\
\hline & & & 實 & & & $\Delta$ & 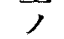 & & 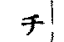 & $=$ & $=$ & & 䈷 & 别 & & 壁 & & x & 周 & \\
\hline & - & $t$ & 驗 & & & $N$ & - & & 氏 & $\exists$ & z & & $\exists$ & シ & & $=$ & & 錐 & 緣 & \\
\hline & $7 i$ & 五 & 间 & & & 時 & 定 & & 器 & $N$ & 0 & & $y$ & 難 & & 近 & & $\neq$ & $=$ & \\
\hline & 何 & [怔 & 數 & & & ㄱ & 部 & & 榙 & $\epsilon$ & & & , & $\neq$ & & $\Rightarrow$ & & 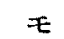 & 存 & \\
\hline & & & & & & $\equiv$ & 位 & & 絽 & J & & & 制 & $x$ & & 程 & & 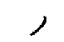 & シ & \\
\hline & & & & & & 3 & & & 胞 & $=$ & & & 雊 & 大 & & 集 & & 多 & 濃 & \\
\hline
\end{tabular}




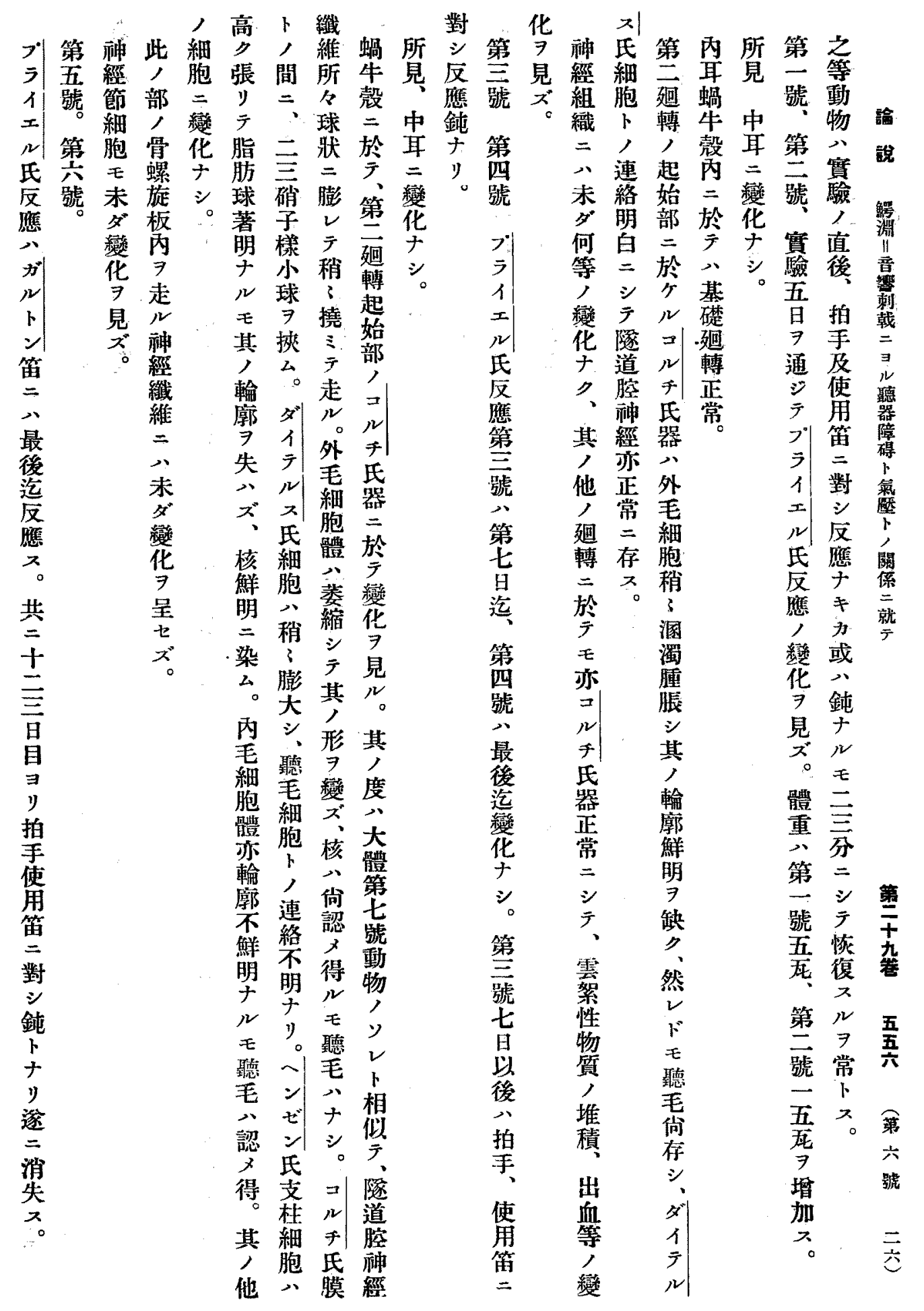




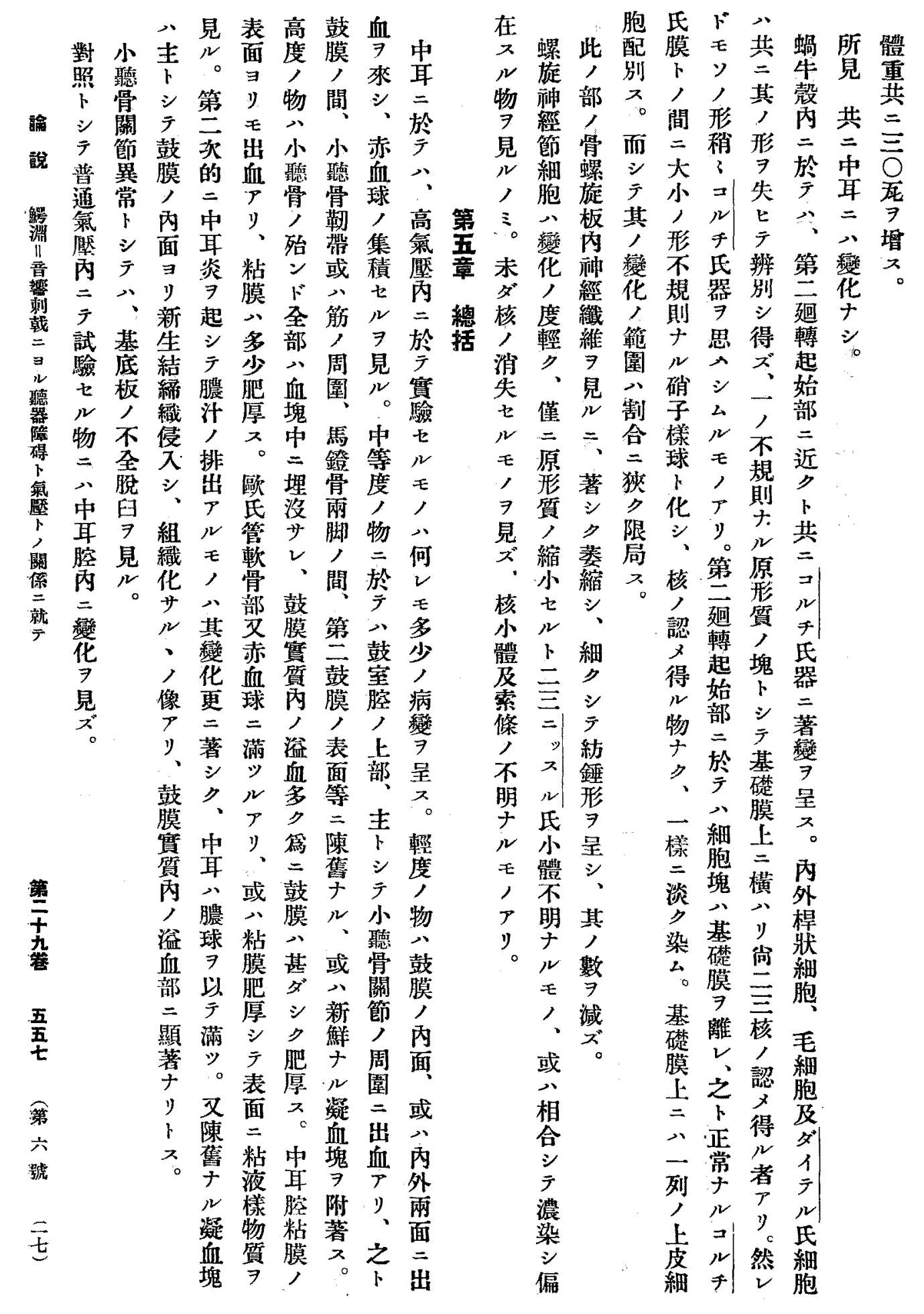




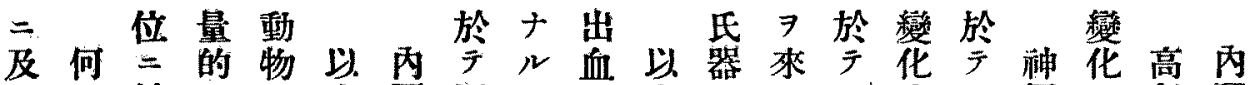

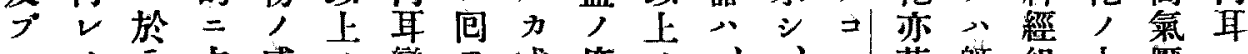

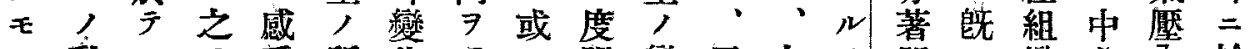
, 動 $、 \ni$ 受所化重

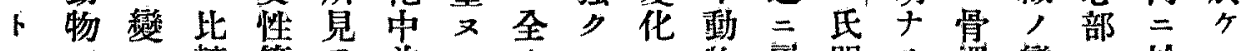

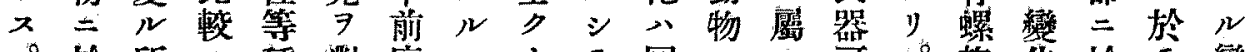

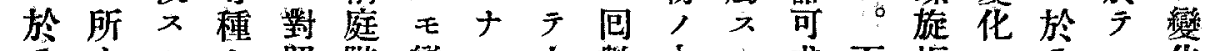

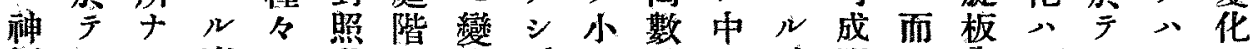

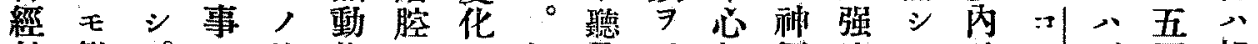

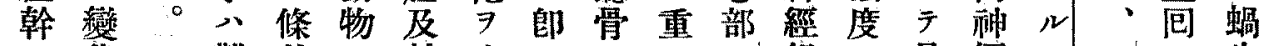

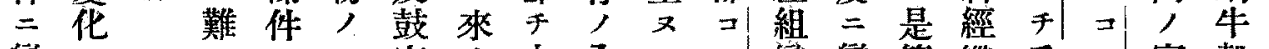
戀

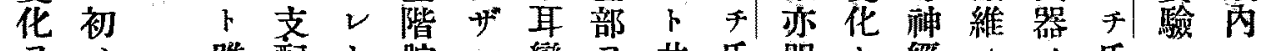

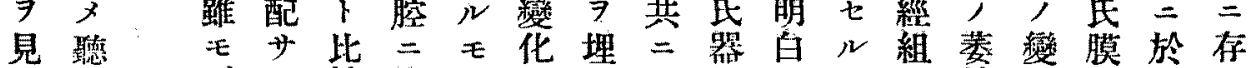

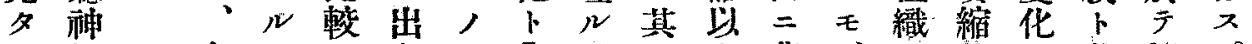
2 經、余、 $、$ 血、内丙，上萎、甚二基既。

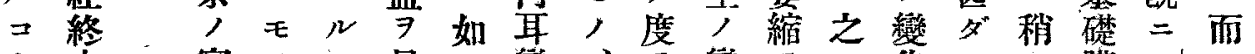

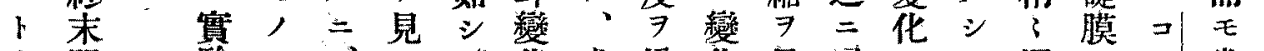

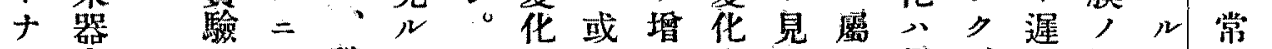

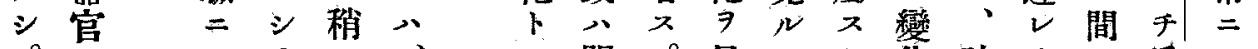
$\exists$ ラ $3 \quad \therefore$ 關 然見

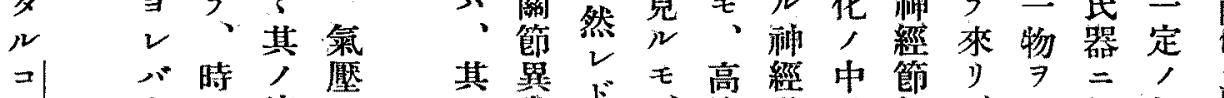

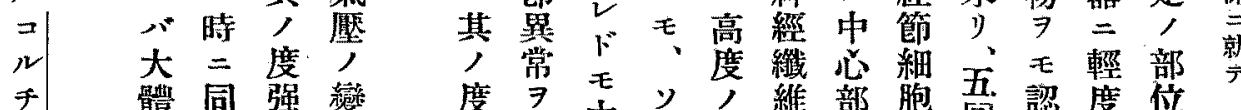
氏 體同强戀, 度 瞽 解

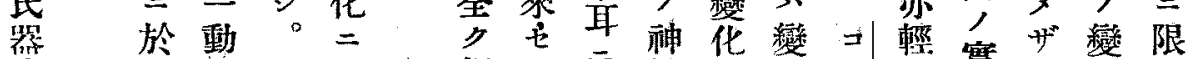

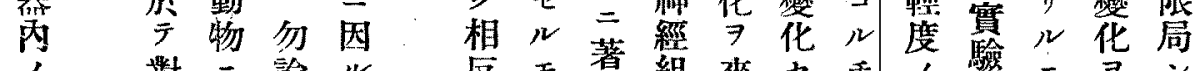

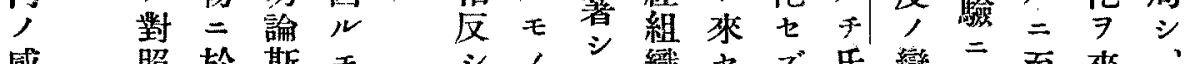

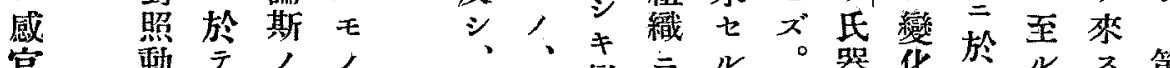

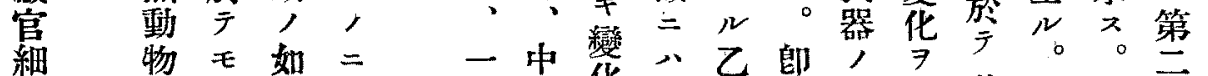
緆

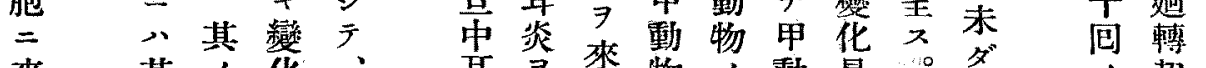
來其, 化、耳 7 東物, 動最。名, 起 、 左

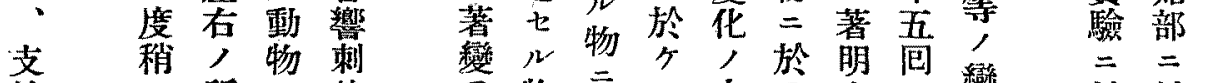

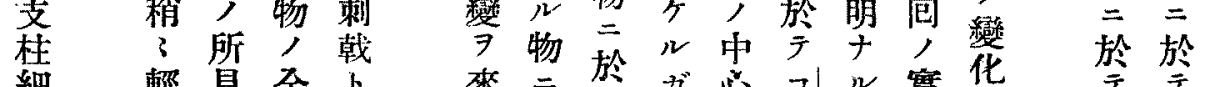

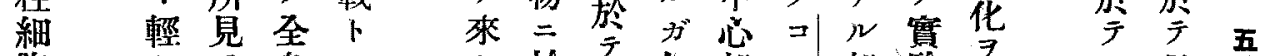

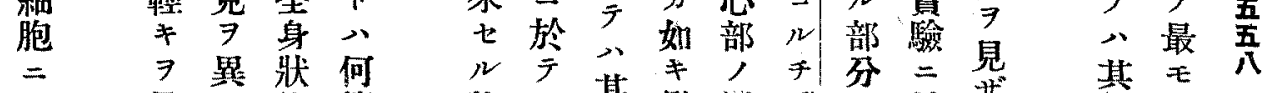

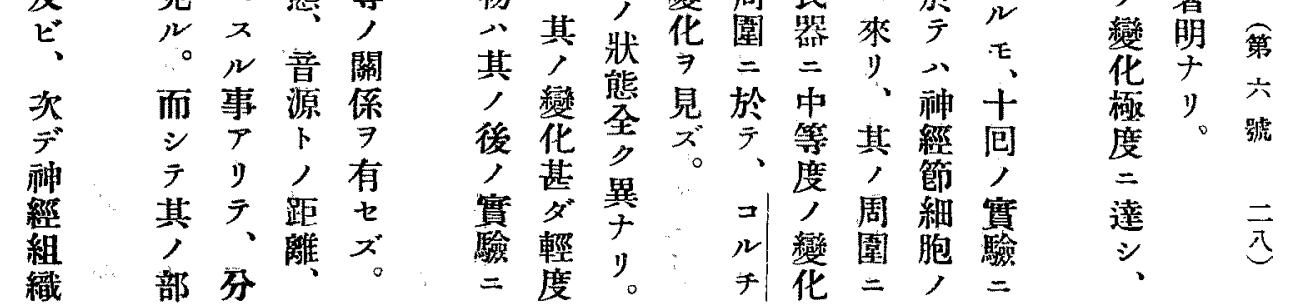




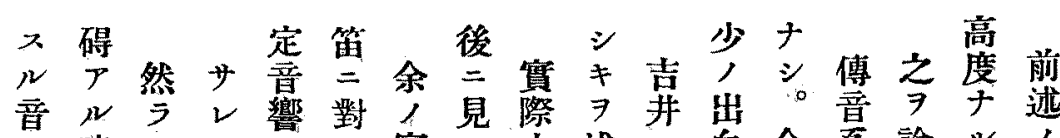

”。更

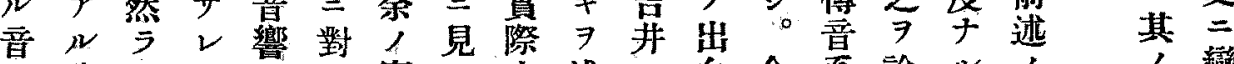

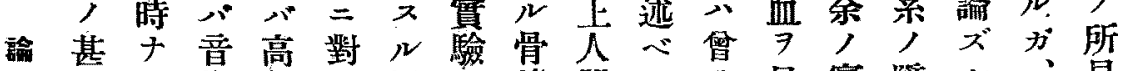

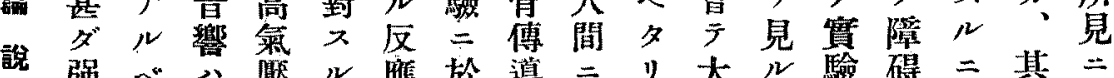

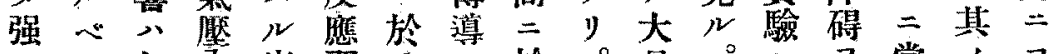

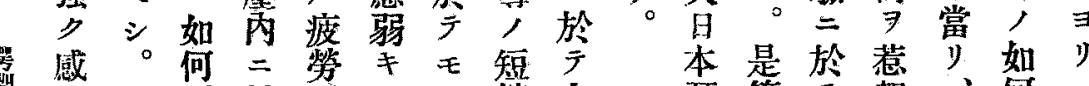

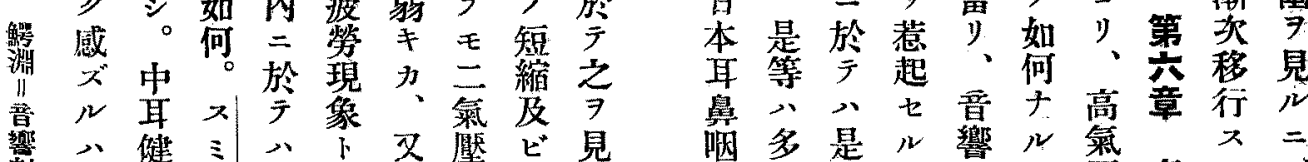

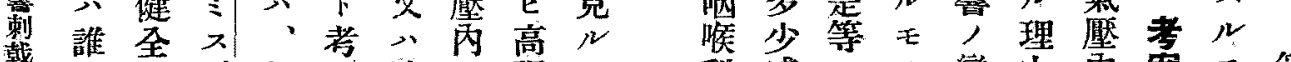

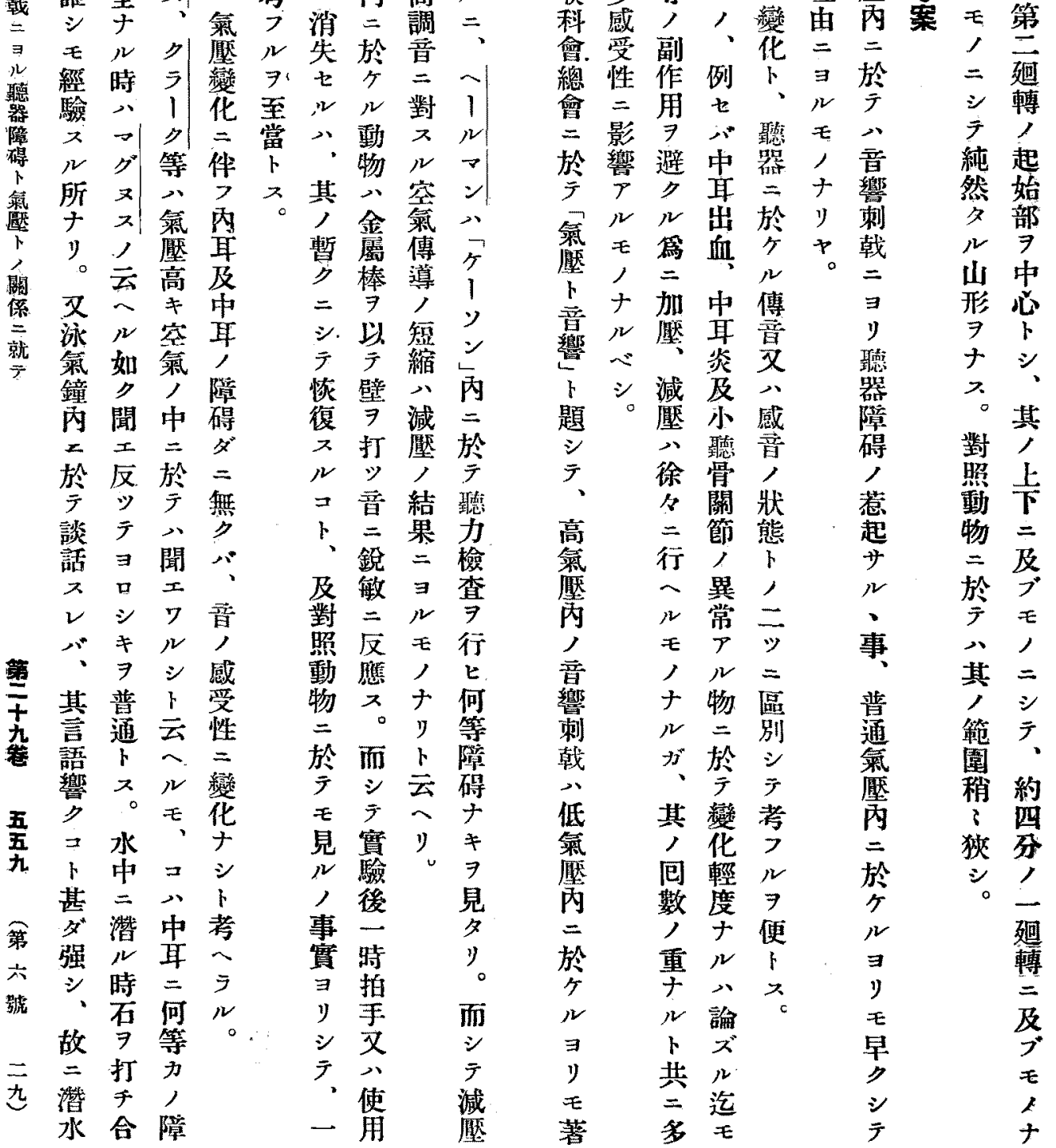




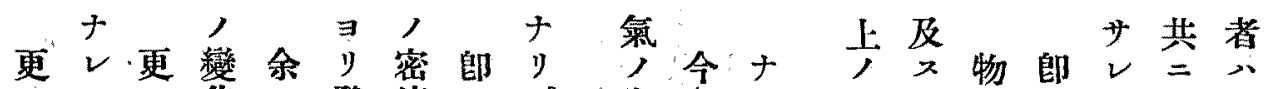

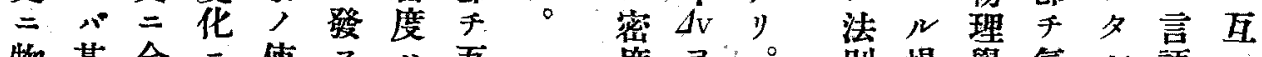

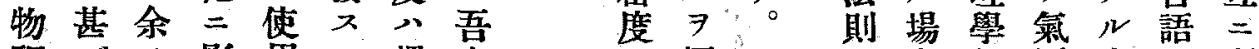
理名，影用 $v$ 溫人極 二合的壓空只弱

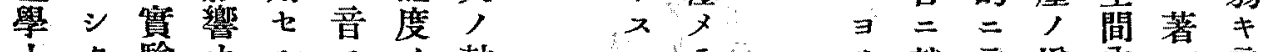

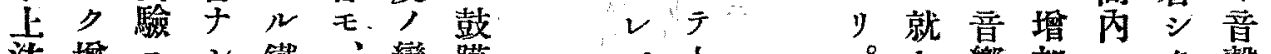

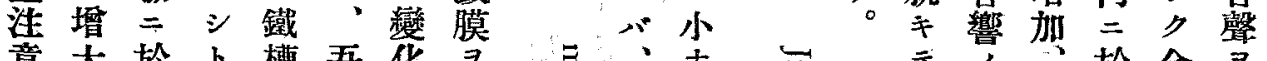

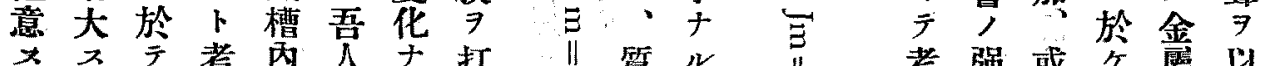

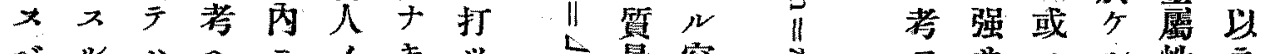

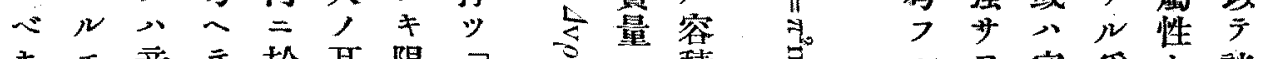

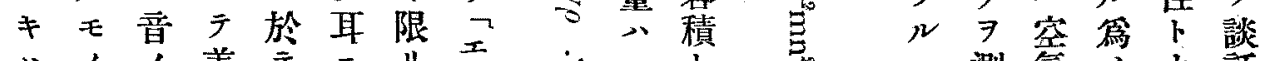

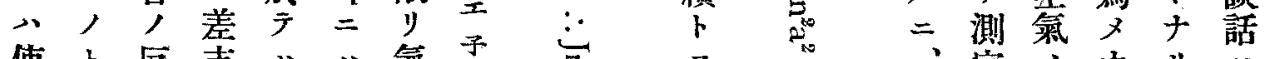

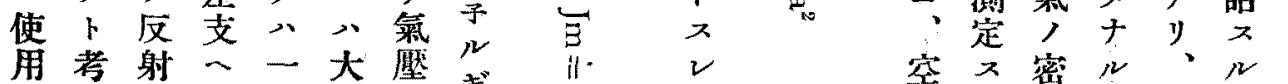

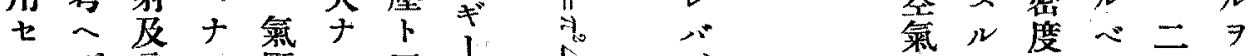

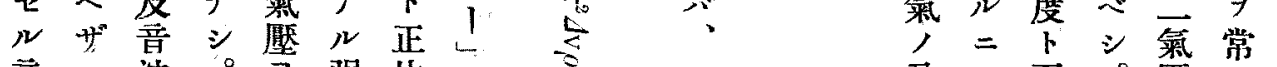
音江波。等强比永 分皮系高艺例振

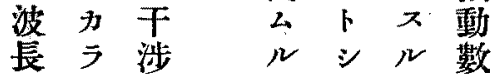

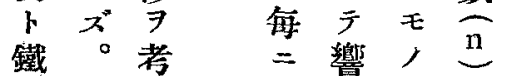
槽、龩萝十及

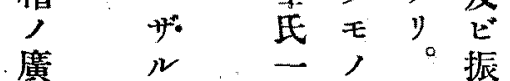
黄可度ナ以幅

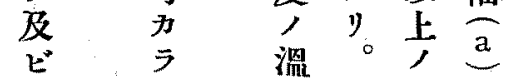
動 ズ㹂理

物音意寻定 位響省りナ 湛公y 于㱠。時

”。郎无永

郎外殆空韫

$\neq \quad=\quad$ 氣,

$\mathrm{C}^{4}$ 漏 $\quad$ J 密 , $v$ 物密度 波 ズ理度 長槽學立比 約 $\exists \quad 1$ -

一质空 亲射氩染, 糎省密同》。

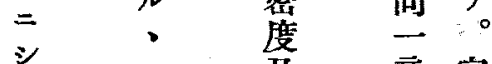

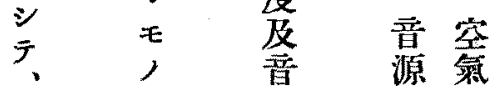

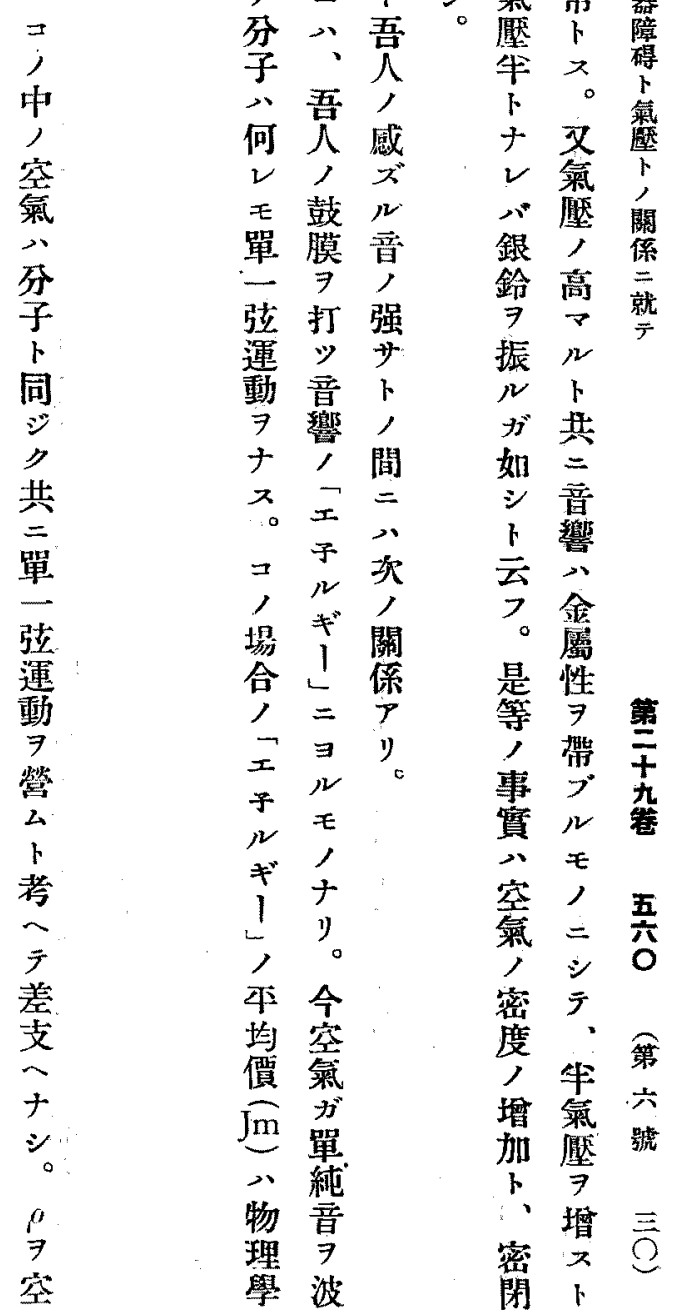


進, モ

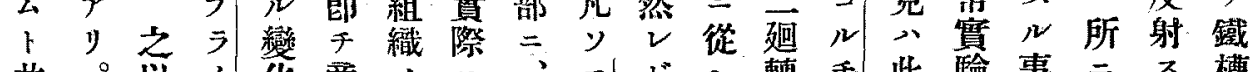

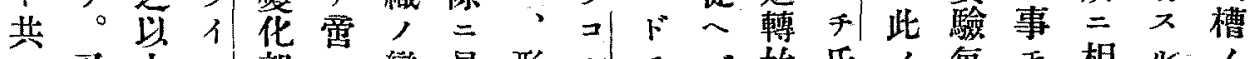

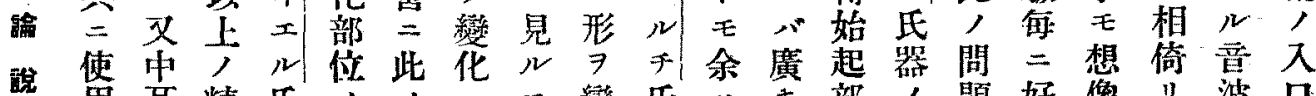

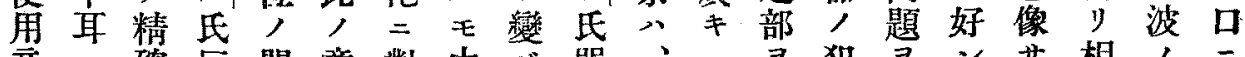

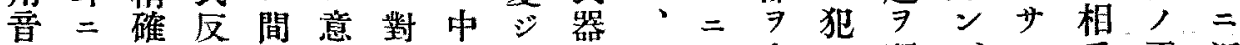

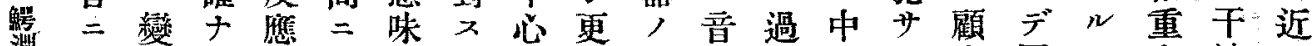

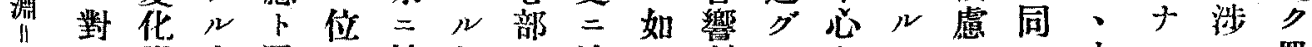

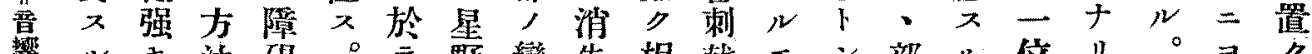

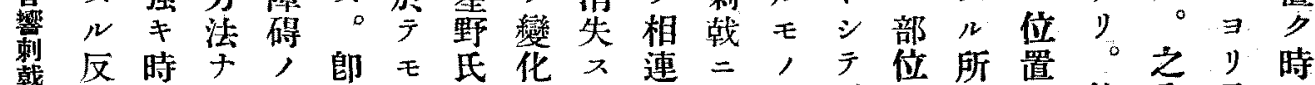

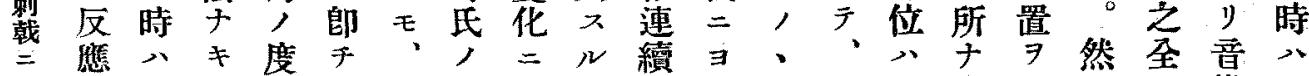

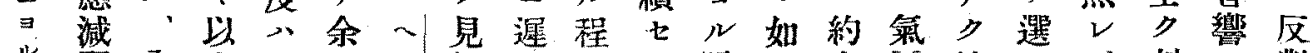

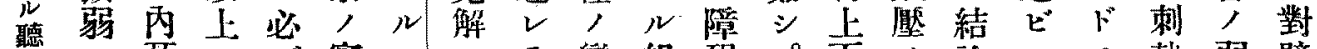

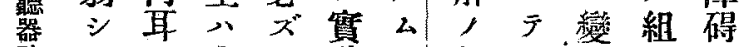
障遂二之シ驗本如來化織, 碍三異二モ三ルクルョ三範

氣消常據一於ッ、王來於園

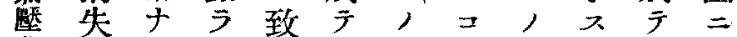
, ス キ ザセモ學入二時心就

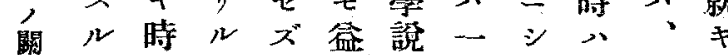

係 就

$$
\text { E }
$$$$
\text { 、生 } \bar{\gamma}
$$$$
\text { 種 }
$$$$
\text { 之理 }
$$

ナ y。x 01 障部接或, 然

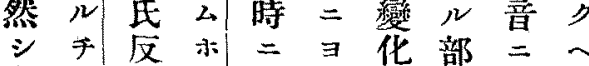
是氐應心其心大等

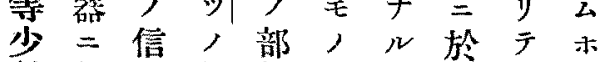

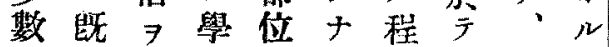

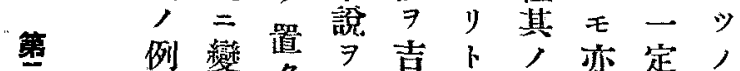
外化二確井考籁何, 說 7 7 足么氏7圍等部

吾 除見足心, 。廣吕位

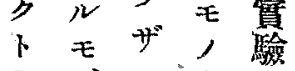

\section{、少 》り些}

第大角請較

六體音, ル

號

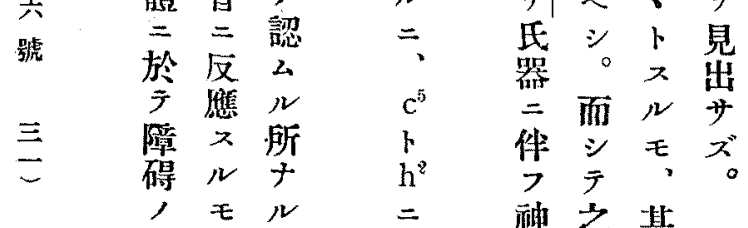
人致如高 余篟刺ザ爱藏 $\therefore \Rightarrow$ 载 二|來 $\forall$ 理 父的胄 カ 內

亏.

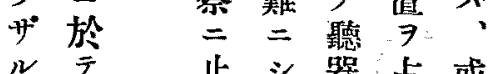

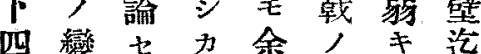
分花り否, 少所心 , 二小筫 $\neq$ 約 一 モ驗位ル四 廻り不二置心十 轉 テ 明於 7 五

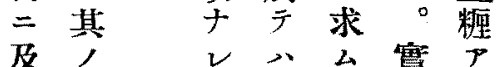

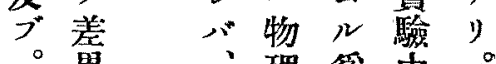
其 7 唯學学動音 , 認 以的儿物 籁 圍

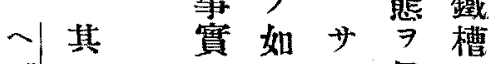
天筑毛年見人 り圍論涉鐵二 $1=$ 上地 槽 常 $=$ ，於可帶丙二比 言 方能 $尹$, 音 ᄀ $\rightarrow$ 求位源甚 高 リ 4 置二ダ

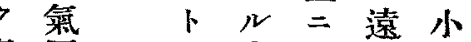
, 事ヨキ 推困り位レ $モ>$ 步 、稍、、、碍概場 佾廣實又, 子所

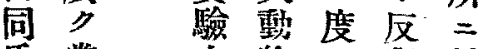

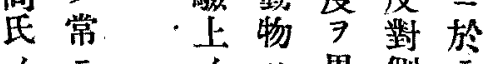




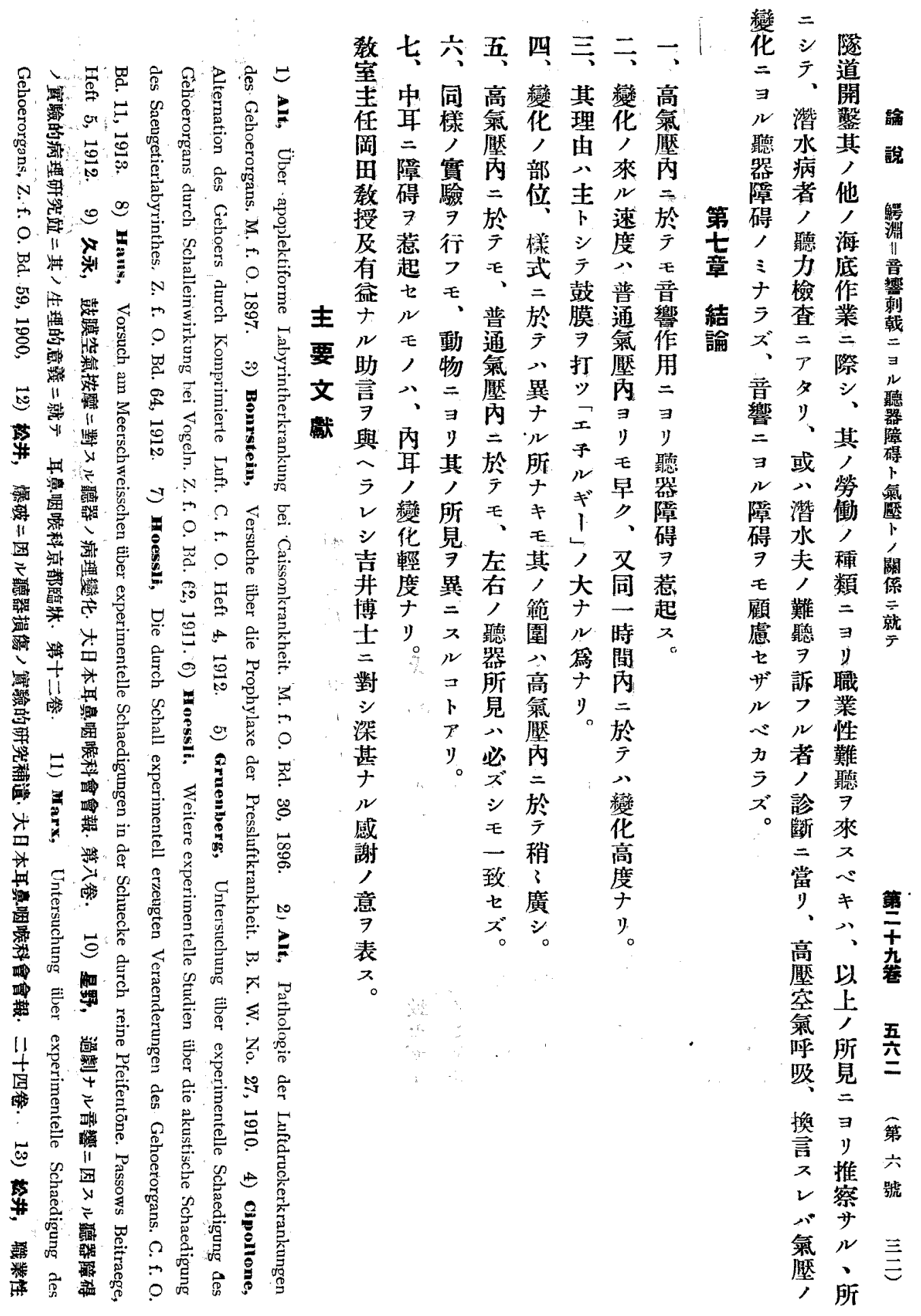


、圖

一第

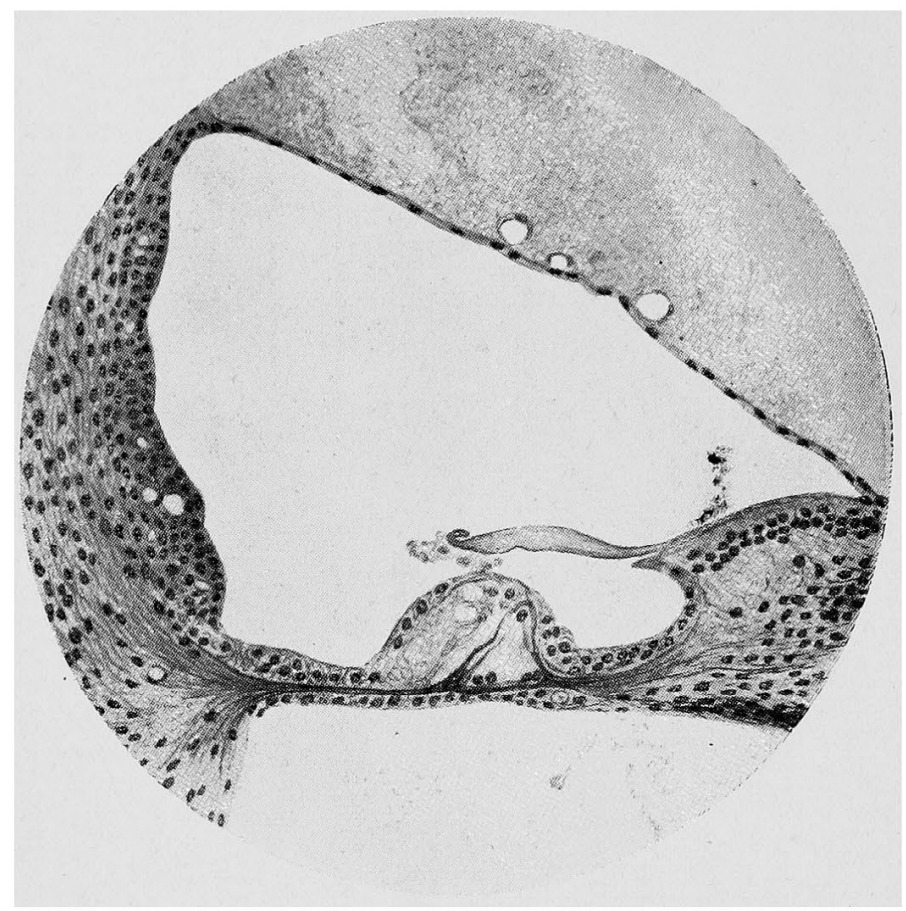

淵

論

文

附

圖

圖

干第

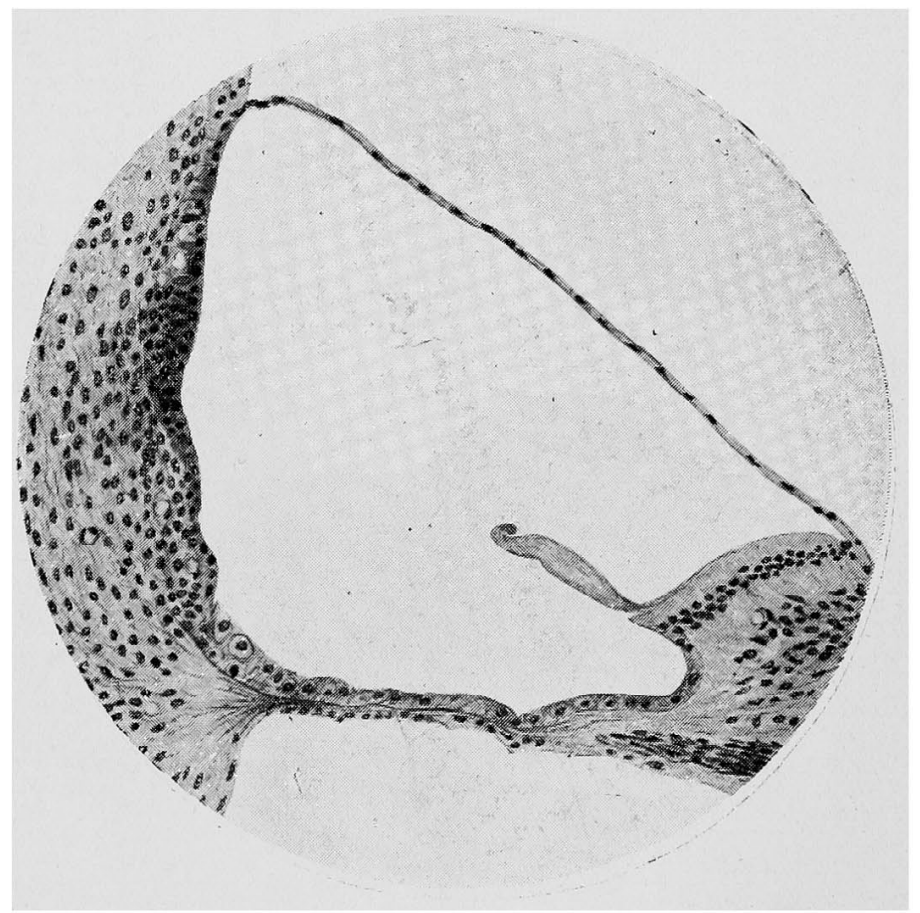


[圆]

$\equiv$

第

䰻

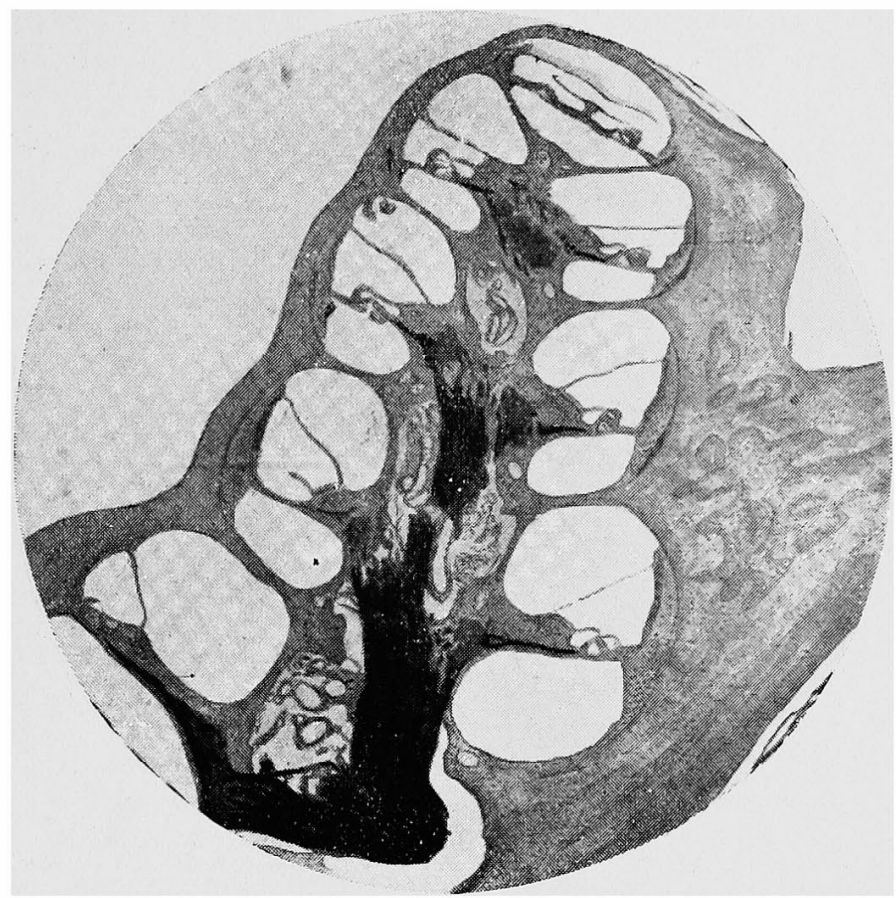

淵

論

文

附

圖

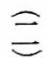

四

第

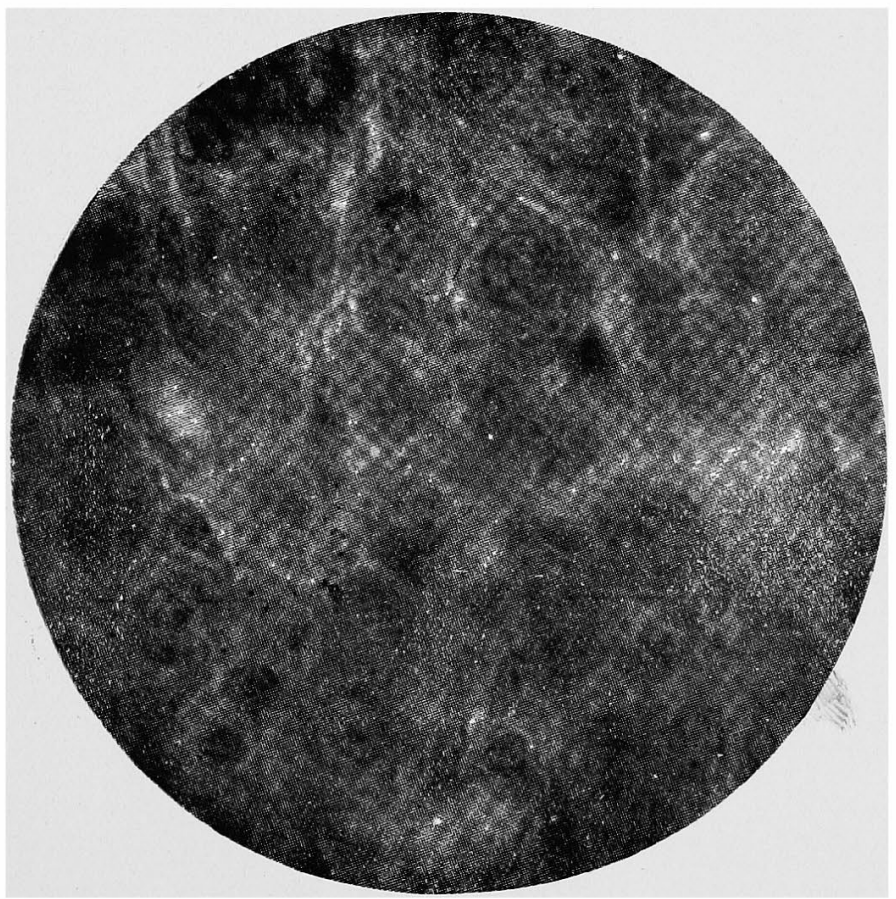



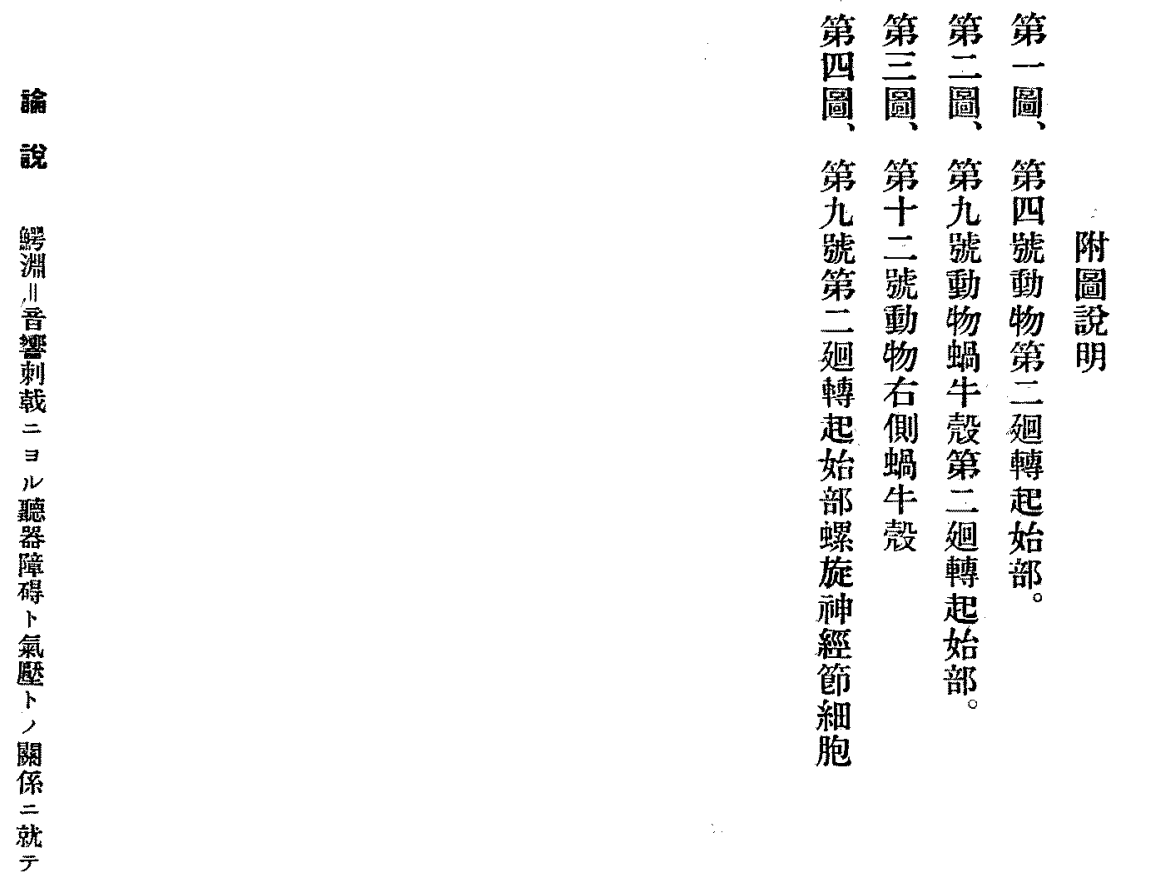

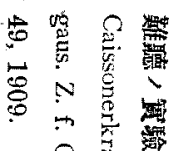

突童

co

$-\overrightarrow{0}$ 可

ज

$\exists$ 可焉

要

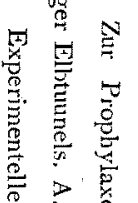

$\leftrightarrows 0$

要索

है

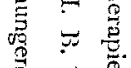

劳

둥

告, 䨔

包

品

을

С. 릉

要

品

舟

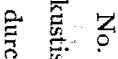

施

总 0

营 $\frac{6}{5}$

‥

害

六

N霡

$\rightarrow 0$

प्र 